\title{
Three-dimensionally ordered macroporous perovskite materials for environmental applications
}

\author{
Chenxi Zhang a,b, Peiyuan Zhao a,c, Shuangxi Liu a,d, Kai Yu b,* \\ a Institute of New Catalytic Materials Science, School of Materials Science and Engineering, National Institute of Advanced Materials, Nankai University, \\ Tianjin 300350, China \\ b MOE Key Laboratory of Pollution Processes and Environmental Criteria and Tianjin Key Laboratory of Environmental Technology for Complex \\ Transmedia Pollution, College of Environmental Science and Engineering, Nankai University, Tianjin 300350, China \\ c Department of Chemistry, University of New Hampshire, Durham, New Hampshire 03824, USA \\ d MOE Key Laboratory of Advanced Energy Materials Chemistry, Collaborative Innovation Center of Chemical Science and Engineering (Tianjin), Tianjin \\ 300072, China
}

\section{A R T I C L E I N F O}

\section{Article history:}

Received 2 January 2019

Accepted 3 March 2019

Published 5 September 2019

\section{Keywords:}

3DOM material

Perovskite

Environmental application

Photocatalysis

Catalytic oxidation

$\mathrm{CO}_{2}$ methanation

Sensor

\begin{abstract}
A B S T R A C T
Three-dimensionally ordered macroporous (3DOM) perovskite materials have attracted the interest from researchers worldwide due to their unique macroporous structure, flexible composition, tailorable physicochemical property, high stability and biocompatibility. In particular, they were widely used in environmental field, such as photocatalysis, catalytic combustion, catalytic oxidation and sensors. In this review, the recent progresses in the synthesis of 3DOM perovskite materials and their environmental applications are summarized. The advantages and the promoting mechanisms of 3DOM perovskite materials for different applications are discussed in detail. Subsequently, the challenges and perspectives on the topic are proposed.
\end{abstract}

(C) 2019, Dalian Institute of Chemical Physics, Chinese Academy of Sciences. Published by Elsevier B.V. All rights reserved.

\section{Introduction}

In recent years, three-dimensionally ordered macroporous (3DOM) materials, also known as inverse opal materials, have been widely studied by researchers worldwide [1-4]. The 3DOM materials possess general features of macroporous material, such as large surface area, high porosity, large pore volume and excellent mass transfer ability. Besides, the materials also own some distinctive characteristics including periodic pore structure, uniform and controllable pore size, as well as the unique optical properties as a kind of photonic crystal derived from their three-dimensional long-range ordered structure [5]. In addition, 3DOM materials with mesoporous walls can be obtained by simply adding surfactants in the fabrication process. The incorporation of mesopores provides more reactive sites for molecules and imparts size-selectivity to the hierarchical porous materials [6].

Perovskite is an abundant compound widely distributed on the earth. The general formula of perovskite is $\mathrm{ABO}_{3}$ (e.g. CaT$\mathrm{iO}_{3}$ ), where the A-site cations are usually rare-earth or alka-

\footnotetext{
* Corresponding author. Tel: +86-22-85358635; E-mail: kaiyu@nankai.edu.cn

This work was supported by the Tianjin Municipal Natural Science Foundation (17JCYBJC22600) and the Fundamental Research Funds for the Central Universities.

DOI: S1872-2067(19)63341-3 | http://www.sciencedirect.com/science/journal/18722067 | Chin. J. Catal., Vol. 40, No. 9, September 2019
} 
line-earth elements, the B-site cations are transition metals and $\mathrm{O}$ is oxygen. Other perovskite-type materials consist of double perovskite [7] $\left(\mathrm{A}_{2} \mathrm{BB}^{\prime} \mathrm{O}_{6}\right.$, e.g. $\left.\mathrm{Sr}_{2} \mathrm{FeMoO}_{6}\right)$, perovskite-like [8] $\left(\mathrm{A}_{2} \mathrm{BO}_{4}\right.$, e.g. $\left.\mathrm{La}_{2} \mathrm{CuO}_{4}\right)$, antiperovskite [9] $\left(\mathrm{AXM}_{3}\right.$, e.g. $\left.\mathrm{CuNNi}_{3}\right)$, post-perovskite [10] $\left(\mathrm{ABO}_{3}\right.$, e.g. $\left.\mathrm{MgSiO}_{3}\right)$ and pre-perovskite [11] $\left(\mathrm{ABO}_{3}\right.$, e.g. $\left.\mathrm{PbTiO}_{3}\right)$. Its low cost, excellent redox property, improved ion mobility, high stability, low toxicity and good biocompatibility make perovskite possible to be broadly used. Through partial or complete substitution of the A-/B-site cations, the physicochemical properties of perovskite materials can be adjusted, giving the perovskite controllable properties and making it a potential research focus.

Recently, because of their tailorable structural and physicochemical properties, ongoing progresses and systematic studies of 3DOM perovskite materials have been reported for numerous applications, such as photocatalysis, soot combustion, catalytic oxidation of volatile organic compounds (VOCs), emission reduction and utilization of greenhouse gases, and sensors for gases or liquids.

Herein, an up to date review focused on the advances of 3DOM perovskite materials for environmental applications is expected urgently due to the rapid development of this field. Although some excellent reviews have been published about perovskite materials [12-16], only certain applications are involved and 3DOM morphology is not mentioned. In the feature article written by Arandiyan et al. [17], the use of porous perovskite and spinel oxides as advanced catalysts for energy conversion applications and various heterogeneous reactions were reviewed, but not focused on the environmental applications. As the consequence, we think it is necessary to write a new review concentrating on 3DOM perovskite materials for environmental applications. In the first part of the review, the general fabrication approach of 3DOM perovskite materials will be provided. Afterwards, we intend to introduce recent progresses of the materials in environmental applications. Lastly, we provide conclusions and the authors' views of future prospects are presented.

\section{Fabrication of 3DOM perovskite materials}

3DOM materials are usually prepared by an etching method, biological template method or colloidal crystal template method. Among these methods, the first two, which require special instruments, strict conditions and complex operations, are difficult for most laboratories. The colloidal crystal template (CCT) method is simple, low-cost and suitable for applications in most laboratories. As the result, it is the most commonly used method for fabricating 3DOM materials [18]. Generally, the preparation of 3DOM materials by CCT method includes the following four steps [19,20]: (1) Synthesis of monodisperse colloidal microspheres; (2) Assembly of monodisperse colloidal microspheres into opal-structured CCT by appropriate methods; (3) Filling and solidifying the voids between the microspheres by appropriate precursor; (4) Calcination to form the skeleton and removing the template. In order to fabricate 3DOM materials with mesoporous walls, the surfactant-assisted method is used, in which surfactants are added into the precursor solution. Conventional surfactants include Pluronic P-123, Pluronic F-127, polyethylene glycol (PEG400), L-lysine, dimethoxytetraethylene glycol (DMOTEG), and cetyltrimethylammonium bromide (CTAB). Scheme 1 shows the schematic diagram of 3DOM materials prepared by CCT method.

Colloidal microspheres used as templates should be chemically stable and easily wetted by the precursor solution. Usually, polystyrene (PS), polymethyl methacrylate (PMMA) and $\mathrm{SiO}_{2}$ colloidal microspheres are selected to fabricate the CCT by self-assembly [21]. The pore size of the 3DOM material can be controlled by adjusting the average particle sizes of the colloidal microspheres. The polymer microspheres can be prepared by soap-free emulsion polymerization method [22,23], and the $\mathrm{SiO}_{2}$ microspheres can be synthesized by Stöber method $[24,25]$. Although the $\mathrm{SiO}_{2} \mathrm{CCT}$ is high-temperature resistance, it can only be removed by the highly corrosive hydrofluoric acid solution, which limits its application. By contrast, the polymer CCT can be easily removed by calcination, making the polymer microspheres more commonly used in fabricating CCT [26,27].

The self-assembly process of the CCT is a critical step in the preparation of 3DOM materials because the order of CCT directly affects the final 3DOM structures. Several methods of assembling monodisperse colloidal microspheres into three-dimensionally ordered CCT have emerged, such as centrifugation, gravity deposition [28,29], accelerated deposition [30], vertical deposition, electrophoretic deposition [31], and self-assembly under confinement [32,33]. Among them, centrifugation is considered as the priority option to assemble CCT, because it is a fast, low-cost and facile method. Moreover, the obtained CCT is highly-ordered.

After the assembly of the colloidal template, choosing reasonable precursors is another critical step of the preparation of 3DOM materials [34]. Specifically, for the preparation of 3DOM perovskite materials, more than one metal cations will be used.

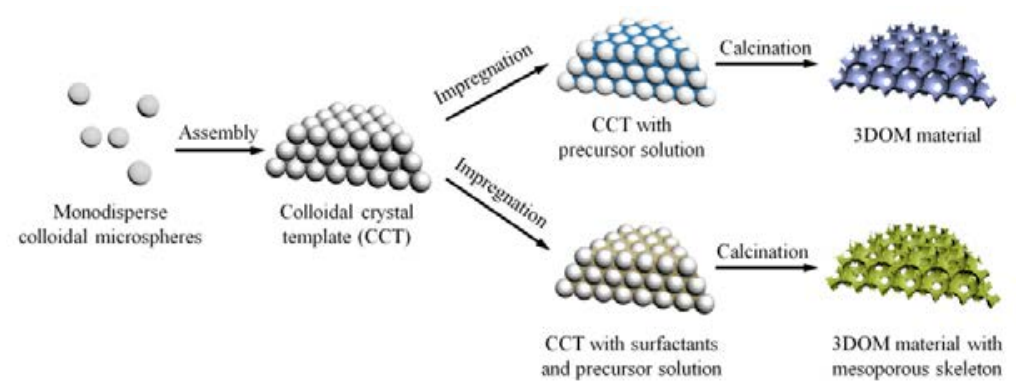

Scheme 1. The preparation process of 3DOM materials by colloidal crystal template method. 
Consequently, the composition and physicochemical properties of precursor solutions, such as $\mathrm{pH}$ and viscosity, are more important. The precursor should be able to (1) fill the voids between the microspheres sufficiently, (2) convert into the desired materials through appropriate reaction, (3) should not interfere with the skeleton structure during the CCT removal process and (4) solidify before the glass transition temperature ( $T_{\mathrm{g}}$ ) of the polymer sphere template [35]. Various materials can be used as precursors, including metal alkoxides, inorganic salts, dispersed nano-microcrystalline particles, and other organic compounds.

A typical synthesis process of 3DOM perovskite materials is illustrated by the fabrication of 3DOM LaMnO 3 [36-38]. Firstly, the uniform ordered PMMA CCT was prepared by the centrifugation. From the scanning electron microscope (SEM) image of PMMA CCT as described in Fig. 1(a), the average diameter of the PMMA microspheres was about $218 \mathrm{~nm}$. Then, $\mathrm{La}\left(\mathrm{NO}_{3}\right)_{3} \cdot 6 \mathrm{H}_{2} \mathrm{O}$ and $\mathrm{Mn}\left(\mathrm{NO}_{3}\right)_{2}$ were dissolved in methanol with L-tryptophan acting as the chelating agent to the obtained precursor solution. After impregnation, filtration and drying, the sample was first heated under a nitrogen atmosphere to solidify the 3DOM structure by carbonization and then calcined in air to form $\mathrm{LaMnO}_{3}$ and remove the CCT. As shown in Fig. 1(b), the 3DOM LaMnO 3 sample with an average pore diameter of about $160 \mathrm{~nm}$ was obtained, which showed shrinkage of $\sim 27 \%$ compared with the PMMA microspheres. If the PEG400 was added in the precursor solution as the surfactant, the $3 \mathrm{DOM} \mathrm{LaMnO}_{3}$ obtained (Fig. 1(c)-(d)) can be found with 3DOM structures which are well maintained and the diameters of the mesopores were about 3-16 $\mathrm{nm}$. The result showed that the addition of surfactants played an important role in the formation of mesopores on the 3DOM skeleton.

\section{Environmental applications of 3DOM perovskite materials}
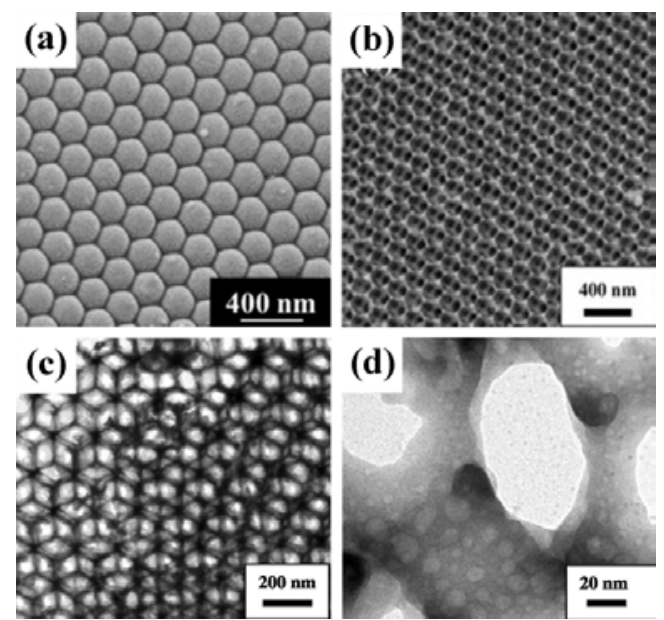

Fig. 1. (a) SEM image of CCT fabricated by PMMA microspheres with an average diameter of ca. $218 \mathrm{~nm}$. Reprinted from [36]. Copyright (2016) American Chemical Society. (b) SEM image of 3DOM LaMnO ${ }_{3}$. Reprinted from [37] with permission from Elsevier. (c-d) TEM images of 3DOM $\mathrm{LaMnO}_{3}$ with mesopores. Reprinted from [38] with permission from Elsevier.

\subsection{Photocatalysis}

As a kind of photonic crystals, the three-dimensionally ordered spatial lattice structures of 3DOM materials denote obvious photonic band gap effect [39] and the slow photon effect $[40,41]$. The incident light with certain wavelengths will be hindered from propagating through the 3DOM materials along a specific crystal direction results in the stop-band reflection, also called photonic band gap [42]. If the photons propagate at the lower (blue edge), or higher (red edge) wavelength edge of the photonic band gap, their group velocity decreases. This phenomenon is called the slow photon effect and is the result of increased interaction between photons and the 3DOM material [43]. When the blue or red edge overlap with the absorption band of these 3DOM semiconductors, the slow photon effect occurs, causing the light utilization efficiency of photocatalyst increases greatly [44,45]. Perovskite materials have shown great potential as efficient photocatalysts due to the unique crystal structures and electronic properties [15]. The band gap and the band edge potential are tunable to utilize visible light and satisfy specific photocatalytic reactions. Moreover, the lattice distortion in perovskite can be used to depress the recombination of photogenerated charge carriers.

Sun et al. [46] synthesized a typical double perovskite 3DOM $\mathrm{Bi}_{2} \mathrm{WO}_{6}$ with $\mathrm{SiO}_{2} \mathrm{CCT}$ and its catalytic activity was evaluated by the decomposition of phenol and aqueous ammonia under a $500 \mathrm{~W}$ Xe lamp. The total organic carbon (TOC) analysis of the phenol solution showed that only $15 \%$ of phenol remained after 60 min irradiation and the Nessler's reagent colorimetric method indicated that $87 \%$ of the ammonia was degraded in $120 \mathrm{~min}$. The $3 \mathrm{DOM} \mathrm{Bi}_{2} \mathrm{WO}_{6}$ exhibited much higher photocatalytic activity than that of the $\mathrm{Bi}_{2} \mathrm{WO}_{6}$ samples prepared by the hydrothermal and the solid-state method. This was attributed to the slow photon effect of 3DOM structure, which can increase the light-harvesting efficiency. Additionally, the highly ordered structure can facilitate the migration of the contaminants.

$\mathrm{Ha}$ et al. [47] employed double perovskite 3DOM $\mathrm{LaSrCoFeO}_{6-\delta}$ as the photocatalyst for the reduction of $\mathrm{CO}_{2}$ to $\mathrm{CH}_{4}$ in the presence of $\mathrm{H}_{2} \mathrm{O}$ vapor by the thermal and photothermal reaction. Due to the composition of double perovskite, the material was self-doped, the heterostructures and the oxygen vacancies were self-formed. Consequently, the absorbance ranges of these double perovskite materials were broadened to the visible light region and the recombination of photogenerated electrons and hole pairs were suppressed. Under $350{ }^{\circ} \mathrm{C}$ and visible light irradiation, the yield of $\mathrm{CH}_{4}$ from $\mathrm{CO}_{2}$ and $\mathrm{H}_{2} \mathrm{O}$ reached $557.88 \mu \mathrm{mol} \cdot \mathrm{g}^{-1}$ over $3 \mathrm{DOM} \mathrm{LaSrCoFeO} 6_{-} \delta$ in $8 \mathrm{~h}$, which was $60 \%$ higher than that of the catalyst without 3DOM morphology, and performed 5 times better than under thermal-only conditions. The solar-to-methane (STM) energy conversion efficiency was $1.933 \%$ for $3 \mathrm{DOM} \mathrm{LaSrCoFeO}_{6-\delta}$ in the photothermal mode. The selectivity and durability of the 3DOM LaSrCoFeO6- $\delta$ were good as well, showing that double perovskites with 3DOM morphology are promising catalysts for the photothermal reduction of $\mathrm{CO}_{2}$ to hydrocarbon fuels.

Although the slow photon effect is regarded as the key fac- 
tor of the improved light harvesting efficiency of these 3DOM photocatalysts, the direct experimental evidence should be provided through controlled experiments by tuning the stop-band of the 3DOM materials [48] or irradiation by monochromatic light [49]. Recently, our group fabricated a series of $3 \mathrm{DOM}^{-\mathrm{SrTiO}_{3}}$ materials with different pore sizes for the generation of $\mathrm{H}_{2}$ by water splitting [50] and demonstrated the slow photon effect of 3DOM photocatalyst in powder suspension photocatalytic water splitting system. As described in Fig. 2(a), the as-synthesized $3 \mathrm{DOM}_{-} \mathrm{SrTiO}_{3}$ catalysts exhibited notably enhanced $\mathrm{H}_{2}$ evolution rate compared with $\mathrm{SS}_{-} \mathrm{SrTiO}_{3}\left(\mathrm{SrTiO}_{3}\right.$ prepared by solid state method) and Disorder-SrTiO ${ }_{3}\left(\mathrm{SrTiO}_{3}\right.$ with disordered macropores), indicating the promoting effect of 3DOM morphology. In order to further investigate the slow photon effect of 3DOM-SrTiO 3 , the monochromatic experiments were carried out as depicted in Fig. 2(b). With the short-wavelength pass filters, the samples represented different activities under the irradiation of light with different wavelengths. When the wavelength of incident light was overlapped with the edges of stop-band of 3DOM materials, the light harvesting efficiency and photocatalytic performance would increase significantly. The results of monochromatic experiments provided the direct experimental evidence of the slow photon effect of $3 \mathrm{DOM}-\mathrm{SrTiO}_{3}$.

Based on pristine $3 \mathrm{DOM}-\mathrm{SrTiO}_{3}$, the ternary composite photocatalysts, including $\mathrm{CdS} / \mathrm{Au} / 3 \mathrm{DOM}_{-} \mathrm{SrTiO}_{3}$ [51], 3DOM-SrTiO $3 / \mathrm{Ag} / \mathrm{Ag}_{3} \mathrm{PO}_{4}$ [52], and Pt@CdS/3DOM-SrTiO 3 [53] were fabricated by our group. Notably enhanced photocatalytic performance was obtained under visible or UV-Vis light irradiation for the photodegradation of organic contaminants and
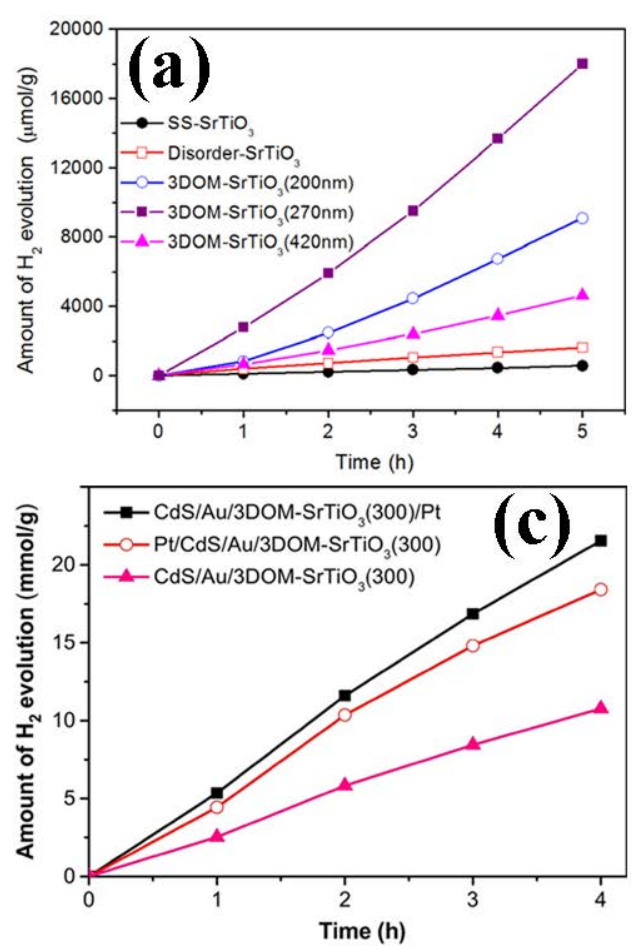

water splitting for $\mathrm{H}_{2}$ evolution. The reduced rates of electron-hole pairs recombination, increased surface plasmon resonance (SPR) effect of noble metal nanoparticles and enhanced light harvesting efficiency by slow photon effect present in the system are all attributed to the increased photocatalytic activity. For example, the ternary $\mathrm{CdS} / \mathrm{Au} / 3 \mathrm{DOM}-\mathrm{SrTiO}_{3}$ composite photocatalysts exhibited excellent efficiency of $\mathrm{H}_{2}$ evolution (up to $5.46 \mathrm{mmol} /(\mathrm{g} \cdot \mathrm{h})$ ) from water splitting under visible light irradiation, as depicted in Fig. 2(c). The mechanism of these systems with remarkable apparent quantum efficiency $(42.2 \%$ at $420 \mathrm{~nm}$ ) is illustrated in Fig. 2(d). Additionally, the 3DOM structure and the crystallinity of the photocatalyst were well maintained under continuous stirring and after successive recycles, suggesting the sufficient durability of these ternary composite materials under photocatalytic conditions.

To summarize, the results above demonstrated that 3DOM perovskite materials have broad prospects in photocatalysis. However, until now, only a limited number of 3DOM perovskite materials were synthesized and applied in the photocatalysis field. Considering of the tremendous application potential of perovskite materials in the photocatalysis and photovoltaic fields, the fabrication of new kinds of 3DOM perovskite photocatalysts are highly desirable. In spite of this, additional research into the promoting mechanism of slow photon effect, as well as the influence of surface microstructure and surface property of 3DOM perovskites are still required.

\subsection{Soot combustion}

As a form of solid contaminants, soot particles emitted from
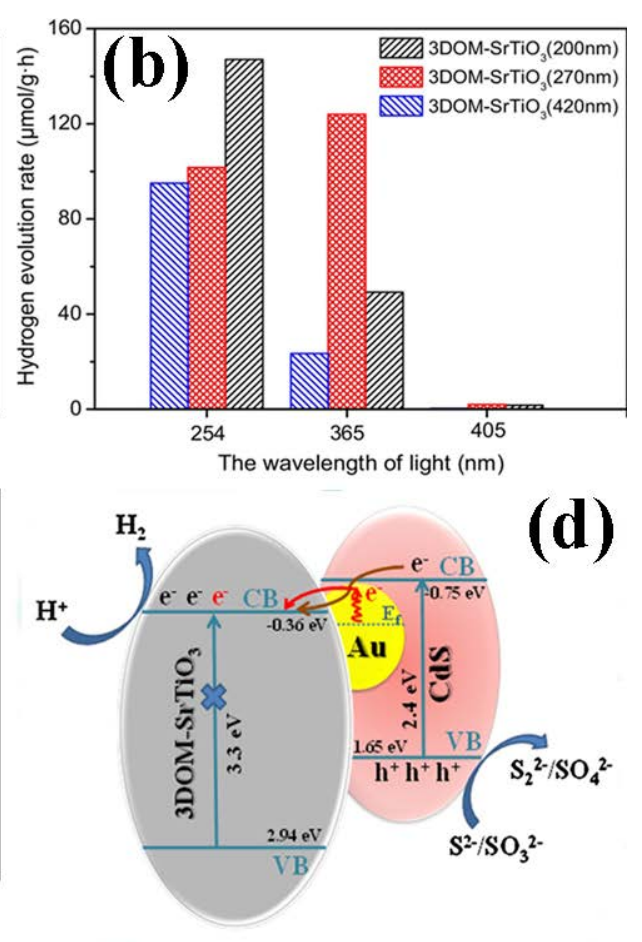

Fig. 2. (a) The efficiencies of $\mathrm{H}_{2}$ evolution over $3 \mathrm{DOM}-\mathrm{SrTiO}_{3}$, Disorder-SrTiO 3 , and $\mathrm{SS}_{-} \mathrm{SrTiO}_{3}$. (b) $\mathrm{H}_{2}$ evolution rate of $3 \mathrm{DOM}-\mathrm{SrTiO}$, with different pore diameters under certain wavelength light irradiation. Reprinted from [50] with permission from Elsevier. (c) The mechanism of $\mathrm{CdS} / \mathrm{Au} / 3 \mathrm{DOM}-\mathrm{SrTiO}_{3}$ catalyst under visible light irradiation. (d) The efficiencies of $\mathrm{H}_{2}$ evolution over Pt-decorated CdS/Au/3DOM-SrTiO 3 and sole $\mathrm{CdS} / \mathrm{Au} / 3 \mathrm{DOM}-\mathrm{SrTiO}_{3}$. Reprinted from [51] with permission from Elsevier. 
diesel engines, act as the main source of PM2.5 and PM10 (particulate matter with diameter $\leq 2.5$ or $\leq 10 \mu \mathrm{m}$ ) in urban ambient conditions [54], and have caused a series of environmental and health problems $[55,56]$. To solve the problem, catalytic combustion is an effective and economical method. The mechanism of soot oxidation is proposed by Liu et al [57]. Oxygen is adsorbed by the catalyst to generate $\mathrm{O}_{2}^{-}$or $\mathrm{O}^{-}$species, then reacts with soot to produce carbon oxides. The oxygen species can also react with $\mathrm{NO}$ in reactant gas to form nitrates or $\mathrm{NO}_{2}$. In the next step, nitrates are decomposed to $\mathrm{N}_{2}$ or $\mathrm{N}_{2} \mathrm{O}$, and $\mathrm{NO}_{2}$ reacts with soot particles which are not adjacent to the catalyst to form NO and $\mathrm{N}_{2}$ according to Eq. (1) and Eq. (2).

$$
\begin{aligned}
\mathrm{C}+2 \mathrm{NO}_{2} & \rightarrow 2 \mathrm{NO}+\mathrm{CO}_{2} \\
\mathrm{C}+\mathrm{NO}_{2} & \rightarrow \mathrm{NO}+\mathrm{CO} \rightarrow 1 / 2 \mathrm{~N}_{2}+\mathrm{CO}_{2}
\end{aligned}
$$

Perovskite materials were considered as promising catalysts candidates for soot oxidation. This is because of their good redox property, high oxygen mobility and thermostability $[58,59]$. Moreover, in this specific form of heterogeneous catalysis, contact between the catalyst and the soot particles is a key factor. The diameter of soot particles ranges between 10 and $50 \mathrm{~nm}$ [60], which is larger than the pore size of mesoporous materials. It leads to the difficulties due to lack of contact between soot particles and active sites on the internal surface of catalysts. Using 3DOM materials which have macroporous structure ( $>50 \mathrm{~nm}$ ) can effectively increase the mass transfer efficiency and the number of available active sites [61-63]. Combining the benefits of the 3DOM structure and excellent reactive properties of perovskite materials could lead to promising catalytic performance. Table 1 lists the 3DOM perovskite catalysts applied in the soot combustion reaction, in which $T_{50 \%}$ mean the temperatures at $50 \%$ of soot conversion. Elements $\mathrm{La}, \mathrm{Ce}, \mathrm{Fe}, \mathrm{Co}$ and $\mathrm{Mn}$ used most frequently in the catalysts and all the catalysts were tested under loose contact conditions.

Sadakane et al. $[26,64]$ studied the effect of 3DOM perovskite catalysts in the combustion of nanosized carbon $(<10$ $\mathrm{nm})$, which was considered a suitable model of soot. The $T_{20}$ of $3 \mathrm{DOM} \mathrm{LaFeO}_{3}$ catalyst was $55^{\circ} \mathrm{C}$ lower than that of non-porous $\mathrm{LaFeO}_{3}$ and the catalytic combustion activity of $3 \mathrm{DOM} \mathrm{LaFeO}_{3}$ was enhanced through addition of more $\mathrm{K}_{2} \mathrm{~S}_{2} \mathrm{O}_{8}$, a polymerization initiator. It can be inferred that the residual $\mathrm{K}$ impurities may partly substitute A-site cations due to the increase of initiator, which decreased of the average pore diameter of 3DOM skeletons from 321 to $127 \mathrm{~nm}$ [78]. However, the carbon particles were still smaller than the macropores of the catalyst and the shrinkage of the pore size did not affect the combustion activity. Although carbon particles are different from soot particles, their research cast light on the study of soot oxidation.

Zhao's group carried out a series of experiments on the application of 3DOM perovskite materials in soot combustion. Starting with $3 \mathrm{DOM}^{\mathrm{LaFeO}} 3$ [65], they found that compared

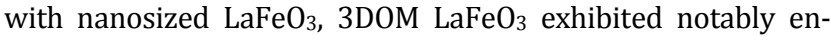
hanced catalytic performance for soot combustion, which was attributed to the improved mass transfer of soot particles. Then, they attempted to dope the B-site of 3DOM $\mathrm{LaFeO}_{3}$ material with Co [66] and found that with the increase of doping level of $\mathrm{Co}$ in $3 \mathrm{DOM} \mathrm{LaFeO}_{3}$ (from $0 \%$ to $50 \%$ ), the activity of the as-prepared catalysts was enhanced. Moreover, the catalytic activity of the 3DOM catalyst can be further improved through grinding to decrease the particle sizes to $5-20 \mu \mathrm{m}$. This indicated the crucial role of mass transfer of soot particles in the reaction. Similarly, the B-site doping of 3DOM $\mathrm{LaMnO}_{3}$ materials with Fe [69] as accomplished and the subsequent materials were used in soot combustion. The influence of macropores, with diameters $140-600 \mathrm{~nm}$, on catalytic performance was studied and it was found that the 3DOM $\mathrm{LaMn}_{1-x} \mathrm{Fe}_{x} \mathrm{O}_{3}$ catalysts with pore diameters above $400 \mathrm{~nm}$ possessed the highest catalytic activities for soot combustion.

Besides the doping in B-site of 3DOM perovskite materials, A-site doping is also an important method to tailor their catalytic performance. Zhao and coworkers [68] synthesized a

Table 1

\begin{tabular}{|c|c|c|c|c|c|}
\hline Catalyst & $\begin{array}{c}\text { Soot/catalyst weight } \\
\text { (mg/mg) }\end{array}$ & Reactant feed & $\begin{array}{l}\text { Heat rate } \\
\left({ }^{\circ} \mathrm{C} / \mathrm{min}\right)\end{array}$ & $T_{50 \%}\left({ }^{\circ} \mathrm{C}\right)$ & Ref. \\
\hline $3 \mathrm{DOM} \mathrm{LaFeO}_{3}$ & $0.909 / 9.09$ & Air, $30 \mathrm{~mL} / \mathrm{min}$ & 10 & 518 & [26] \\
\hline 3DOM LaFeO 3 & $0.909 / 9.09$ & Air, $50 \mathrm{~mL} / \mathrm{min}$ & - & 195 a & [64] \\
\hline $3 \mathrm{DOM} \mathrm{LaFeO}_{3}$ & $10 / 100$ & $0.2 \% \mathrm{NO}, 5 \% \mathrm{O}_{2}$, He balance, $50 \mathrm{~mL} / \mathrm{min}$ & 2 & 412 & [65] \\
\hline $3 \mathrm{DOM} \mathrm{LaCo} 0.5 \mathrm{Fe}_{0.5} \mathrm{O}_{3}$ & $10 / 100$ & $0.2 \% \mathrm{NO}, 5 \% \mathrm{O}_{2}$, Ar balance, $50 \mathrm{~mL} / \mathrm{min}$ & 2 & 397 & [66] \\
\hline $0.04 w t \% A u / 3 D^{2} M \mathrm{LaFeO}_{3}(3.0 \mathrm{~nm})$ & $10 / 100$ & $0.2 \% \mathrm{NO}, 5 \% \mathrm{O}_{2}$, Ar balance, $50 \mathrm{~mL} / \mathrm{min}$ & 2 & $368^{b}$ & [67] \\
\hline $3 \mathrm{DOM} \mathrm{La} 0.9 \mathrm{~K}_{0.1} \mathrm{CoO}_{3}$ & $10 / 100$ & $0.2 \% \mathrm{NO}, 5 \% \mathrm{O}_{2}$, Ar balance, $50 \mathrm{~mL} / \mathrm{min}$ & 2 & 378 & [68] \\
\hline 3DOM LaMn $0.95 \mathrm{Fe}_{0.05} \mathrm{O}_{3}$ & $10 / 100$ & $0.2 \% \mathrm{NO}, 5 \% \mathrm{O}_{2}$, Ar balance, $50 \mathrm{~mL} / \mathrm{min}$ & 2 & 392 b & [69] \\
\hline $1.25 \mathrm{wt} \% \mathrm{Au} / 3 \mathrm{DOM} \mathrm{LaFeO} 3$ & $10 / 100$ & $0.2 \% \mathrm{NO}, 5 \% \mathrm{O}_{2}$, Ar balance, $50 \mathrm{~mL} / \mathrm{min}$ & 2 & 387 & [70] \\
\hline $3 \mathrm{DOM} \mathrm{LaCoO} 3 / \gamma-\mathrm{Al}_{2} \mathrm{O}_{3} /$ cordierite & $200 / 3000$ & $0.2 \% \mathrm{NO}, 5 \% \mathrm{O}_{2}$, Ar balance, $50 \mathrm{~mL} / \mathrm{min}$ & 2 & 348.4 & {$[71]$} \\
\hline 3DOM La0.7 $\mathrm{Ce}_{0.3} \mathrm{Fe}_{0.4} \mathrm{Co}_{0.6} \mathrm{O}_{3}$ & $20 / 180$ & $0.05 \% \mathrm{NO}, 5 \% \mathrm{O}_{2}, \mathrm{~N}_{2}$ balance, $100 \mathrm{~mL} / \mathrm{min}$ & 2 & 410 & [72] \\
\hline $\mathrm{KNO}_{3} / 3 \mathrm{DOM} \mathrm{La} 0.8 \mathrm{Ce}_{0.2} \mathrm{Mn}_{0.6} \mathrm{Fe}_{0.4} \mathrm{O}_{3}$ & $20 / 180$ & $20 \% \mathrm{O}_{2}, \mathrm{~N}_{2}$ balance, $50 \mathrm{~mL} / \mathrm{min}$ & 2 & 379 & [73] \\
\hline Si doped 3DOM La ${ }_{0.8} \mathrm{~K}_{0.2} \mathrm{CoO}_{3}$ & $20 / 180$ & $0.05 \% \mathrm{NO}, 5 \% \mathrm{O}_{2}, \mathrm{~N}_{2}$ balance, $50 \mathrm{~mL} / \mathrm{min}$ & 2 & 396 & [74] \\
\hline $\mathrm{K}-\mathrm{Mn} / 3 \mathrm{DOM} \mathrm{La} 0.8 \mathrm{Ce}_{0.2} \mathrm{FeO}_{3}$ & $20 / 180$ & $0.05 \% \mathrm{NO}, 5 \% \mathrm{O}_{2}, \mathrm{~N}_{2}$ balance & 2 & 377 & [75] \\
\hline $3 \mathrm{DOM} \mathrm{La}_{0.8} \mathrm{Ce}_{0.2} \mathrm{CrO}_{\delta}$ & $20 / 180$ & $0.05 \% \mathrm{NO}, 5 \% \mathrm{O}_{2}, \mathrm{~N}_{2}$ balance, $50 \mathrm{~mL} / \mathrm{min}$ & 2 & 425 & [76] \\
\hline 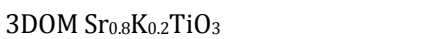 & $5 / 45$ & $0.05 \% \mathrm{NO}, 20 \% \mathrm{O}_{2}, \mathrm{~N}_{2}$ balance, $100 \mathrm{~mL} / \mathrm{min}$ & 5 & 367 & [77] \\
\hline
\end{tabular}

Summary of 3DOM perovskite catalysts for soot combustion.

a This datum is $T_{20}$, which means $20 \mathrm{wt} \%$ of the carbon particles are oxidized.

b The data are $T_{\mathrm{m}}$, which mean the temperatures by which the combustion rate of soot is maximum during the temperature-programmed oxidation procedure. 
K-substituted catalysts, 3DOM $\mathrm{La}_{1-x} \mathrm{~K}_{x} \mathrm{CoO}_{3}(x=0-0.3)$. Compared with non-doped $3 \mathrm{DOM} \mathrm{LaCoO}_{3}$, the K-substituted catalyst exhibited better redox property and higher activity in soot combustion, comparable to a Pt catalyst. Usually, the B-site cations in perovskite-type oxide catalyst acted as the active center in soot combustion. Partial replacement of $\mathrm{La}^{3+}$ at A-site by $\mathrm{K}^{+}$ions with $\mathrm{KNO}_{3}$ can increase the oxidation state of B-site cations or form the oxygen vacancies necessary to keep the electron neutrality of this material. As the consequence, the oxidizability of B-site cations was obviously increased and the mobility of lattice oxygen was accelerated. Besides, the substitution enriched the alkali metal cations on the surface of the catalyst and therefore created basic sites, which can adsorb nitrogen oxides and produce active surface oxygen species for soot combustion $[79,80]$. The addition of $\mathrm{KNO}_{3}$ may facilitate the contact between soot and catalyst. By the reaction $2 \mathrm{KNO}_{3}+$ $\mathrm{C} \rightarrow 2 \mathrm{KNO}_{2}+\mathrm{CO}_{2}, \mathrm{KNO}_{3}$ also acted as the catalyst [81]. Moreover, $\mathrm{K}$ may modify the crystallographic orientation of the catalyst and promote the exposure of active facets [82]. All of these effects are all benefits to soot combustion. Similar results were reported also by Guan and coworkers in $\mathrm{K}$ doped 3DOM $\mathrm{LaCoO}_{3}$ [74] and 3DOM $\mathrm{SrTiO}_{3}$ [77] materials. They also studied the catalytic performance in soot combustion using A-site substituted $\mathrm{Ce}^{3+}$ 3DOM perovskite materials, including $\mathrm{La}_{0} \mathrm{Ce}_{0 .} \mathrm{FeO}_{3}$ [75], $\mathrm{La}_{1-x} \mathrm{Ce}_{x} \mathrm{CrO}_{\delta}$ [76], and the co-doping 3DOM perovskite materials in A-site and B-site, such as $\mathrm{La}_{1-x} \mathrm{Ce}_{x} \mathrm{Fe}_{1-y} \mathrm{Co}_{y} \mathrm{O}_{3}$ [72] and $\mathrm{La}_{0.8} \mathrm{Ce}_{0.2} \mathrm{Mn}_{1-x} \mathrm{Fe}_{x} \mathrm{O}_{3}$ [73]. In these reports, the partial substitution of $\mathrm{La}^{3+}$ by $\mathrm{Ce}^{3+}$ can hinder the increase of crystal size and prevent the 3DOM structure from being destroyed. In addition, as an appropriate oxygen storage carrier, $\mathrm{Ce}^{3+}$ improved the oxygen species concentration.

Recently, 3DOM $\mathrm{LaCoO}_{3}$ was coated on monolith cordierite substrate using a dip-coating method by employing $\gamma-\mathrm{Al}_{2} \mathrm{O}_{3}$ as the washcoat [71]. The catalyst maintained both the 3DOM structure of the coating layer and the mechanical properties of the ceramic substrate. Coating the porous hollow $\gamma-\mathrm{Al}_{2} \mathrm{O}_{3}$ nanoparticles further increased the surface area of the catalyst, which resulted in an improved activity of the 3DOM La$\mathrm{CoO}_{3} / \gamma-\mathrm{Al}_{2} \mathrm{O}_{3} /$ cordierite catalyst for soot combustion. Furthermore, the durability of the composite material was also enhanced due to the thermal stability of $\gamma-\mathrm{Al}_{2} \mathrm{O}_{3}$. This work offered a new route for more efficient utilization of the 3DOM materials.

Although the non-noble metal catalysts were widely researched and promising catalytic performance was obtained for diesel soot combustion, it is still a huge challenge to get an ignition temperature $\left(T_{\mathrm{ig}}\right)$ less than $250{ }^{\circ} \mathrm{C}$. Therefore, modification of noble metal nanoparticles, such as $\mathrm{Au}$, on the inner surface of 3DOM perovskite materials was carried out to further decrease the $T_{\text {ig. }}$. Zhao and coworkers [67] used a hydrogen gas-bubbling-assisted membrane reduction method to prepare the 3DOM Au/LaFeO 3 catalysts, as described in Fig. 3. Compared with $3 \mathrm{DOM} \mathrm{LaFeO}_{3}$, the $0.04 w \mathrm{wt} \% \mathrm{Au} / 3 \mathrm{DOM} \mathrm{LaFeO}_{3}$ catalysts exhibited decreased $T_{\text {ig }}$ (decrease from 347 to $228{ }^{\circ} \mathrm{C}$ ). The role of Au nanoparticles in this situation was considered to be the adsorption and activation of oxygen. In another article published by Zhao's group [70], the enhanced activity of
$\mathrm{Au} / 3 \mathrm{DOM} \mathrm{LaFeO}_{3}$ was further discussed. The active oxygen species of the catalysts can be derived from two approaches. One is direct activation of oxygen on the surface of Au nanoparticles, and the other is originated from the synergetic effect of $\mathrm{Au}-3 \mathrm{DOM} \mathrm{LaFeO}_{3}$ during which the induced support may serve as the reservoir for oxygen [83]. As the consequence, the oxidation was accelerated and a better performance was obtained. In addition, the increasing $\mathrm{Au}$ particle size would lead to a decrease of d-electron density, which was unfavorable for the adsorption and activation of oxygen. It indicated that the $\mathrm{Au}$ particle size was an important factor in the reaction.

\subsection{VOCs oxidation}

Mainly coming from industrial emission and traffic exhaust, VOCs, such as toluene and 1,2-dichloroethane, not only cause environmental pollution but also threaten human health $[84,85]$. Similar to soot combustion, perovskite materials exhibit a huge potential in the catalytic elimination of VOCs, due to their low oxidation temperature, high oxygen mobility, low cost and excellent thermal stability $[13,86,87]$. It has been reported that the dissociation of the weakest $\mathrm{C}-\mathrm{H}$ bond is the rate-determining step in the oxidation of VOCs [88-90]. By doping other elements or changing the oxidation state of B-site cation, the surface oxygen vacancy is formed and the redox property of the catalyst is altered. As the result, the bond dissociation energy is decreased and the reaction is accelerated. Because of the interconnected pore architecture of 3DOM catalysts, high mass transfer performances were shown in recent research [91-93]. Furthermore, taking into account of the smaller molecular size of VOCs, surfactants are usually used as the mesoporous porogens merged with CCT to fabricate the 3DOM materials with mesoporous skeletons. Table 2 illustrates the catalytic performance of 3DOM perovskite catalysts and their experimental conditions for toluene oxidation, in which $T_{10 \%}, T_{50 \%}$ and $T_{90 \%}$ represent the temperatures corresponding to toluene conversions of $10 \%, 50 \%$, and $90 \%$, respectively. In addition, the activation energies $\left(E_{\mathrm{a}}\right)$, specific reaction rates and turnover frequency (TOF) values of these reaction systems are also involved in Table 2.

It can be seen from Table 2 that the catalytic activities of the 3DOM perovskite materials are in the order of cobaltates > manganates $>$ ferrites in toluene oxidation, which are con-
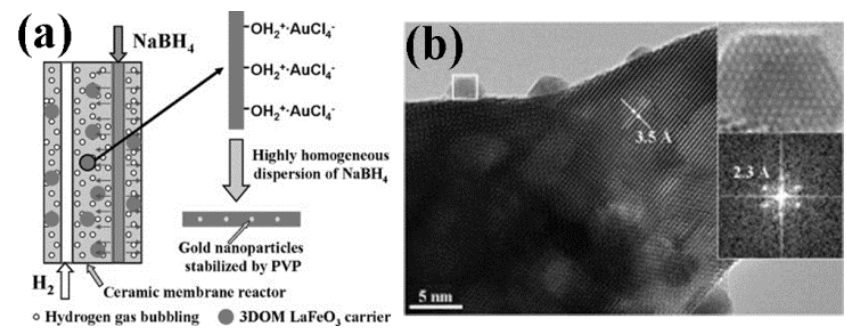

Fig. 3. (a) Preparation of $\mathrm{Au}$ nanoparticles on $3 \mathrm{DOM} \mathrm{LaFeO}_{3}$ carrier by gas-bubbling-assisted membrane reduction method. (b) The HRTEM image of 3DOM $0.04 \mathrm{wt} \% \mathrm{Au} / \mathrm{LaFeO}_{3}$ sample. The inset images are the enlarged $\mathrm{Au}$ particle whose lattice fringes correspond to the fcc (111) plane at $2.3 \AA$ in the fast Fourier transform (FFT) image. Reprinted from [67] with permission from Wiley-VCH. 
Table 2

Summary of 3DOM perovskite catalysts for toluene oxidation.

\begin{tabular}{|c|c|c|c|c|c|c|c|c|c|c|}
\hline \multirow{2}{*}{ Catalyst } & \multirow{2}{*}{$\begin{array}{l}\text { Weight } \\
\text { (g) }\end{array}$} & \multirow{2}{*}{ Reactant feed } & \multirow{2}{*}{$\begin{array}{c}\text { Space } \\
\text { velocity } \\
(\mathrm{mL} /(\mathrm{g} \cdot \mathrm{h}))\end{array}$} & \multicolumn{3}{|c|}{ Toluene conversion capacity } & \multirow{2}{*}{$\begin{array}{c}\text { Specific reac- } \\
\text { tion rate } \\
\left(\mu \mathrm{mol} /\left(\mathrm{g}_{\mathrm{cat}} \cdot \mathrm{s}\right)\right)\end{array}$} & \multirow{2}{*}{$\begin{array}{l}\mathrm{TOF}_{\mathrm{Au}} \\
\left(\mathrm{s}^{-1}\right)\end{array}$} & \multirow{2}{*}{$\begin{array}{c}E_{\mathrm{a}} \\
(\mathrm{kJ} / \mathrm{mol})\end{array}$} & \multirow{2}{*}{ Ref. } \\
\hline & & & & $T_{10 \%}\left({ }^{\circ} \mathrm{C}\right)$ & $T_{50 \%}\left({ }^{\circ} \mathrm{C}\right)$ & $T_{90 \%}\left({ }^{\circ} \mathrm{C}\right)$ & & & & \\
\hline 3DOM LaMnO 3 & $0.1-0.2$ & $\begin{array}{l}0.1 \% \text { toluene, } 40 \% \mathrm{O}_{2}, \mathrm{~N}_{2} \\
\text { balance, } 33.3 \mathrm{~mL} / \mathrm{min}\end{array}$ & 20000 & 169 & 222 & 243 & - & - & 58 & {$[38,94]$} \\
\hline $3 \mathrm{DOM} \mathrm{SrFeO}_{3-\delta}$ & 0.1 & $\begin{array}{c}0.1 \% \text { toluene, } 40 \% \mathrm{O}_{2}, \mathrm{~N}_{2} \\
\text { balance, } 33.3 \mathrm{~mL} / \mathrm{min}\end{array}$ & 20000 & - & 292 & 340 & - & - & - & {$[95,96]$} \\
\hline 3DOM La0.6 $\mathrm{Sr}_{0.4} \mathrm{FeO}_{3-\delta}$ & 0.1 & $\begin{array}{l}0.1 \% \text { toluene, } 40 \% \mathrm{O}_{2}, \mathrm{~N}_{2} \\
\text { balance, } 33.3 \mathrm{~mL} / \mathrm{min}\end{array}$ & 20000 & 54 & 225 & 280 & - & - & - & [97] \\
\hline $\begin{array}{l}3 \mathrm{wt} \% \mathrm{Co}_{3} \mathrm{O}_{4} / 3 \mathrm{DOM} \\
\mathrm{Eu}_{0.6} \mathrm{Sr}_{0.4} \mathrm{FeO}_{3}\end{array}$ & 0.1 & $\begin{array}{l}0.1 \% \text { toluene, } 40 \% \mathrm{O}_{2}, \mathrm{~N}_{2} \\
\text { balance, } 33.3 \mathrm{~mL} / \mathrm{min}\end{array}$ & 20000 & 213 & 251 & 269 & - & - & 75.2 & [98] \\
\hline $\begin{array}{l}\text { 3DOM } \\
\mathrm{La}_{0.6} \mathrm{~S}_{\mathrm{r} 0.4} \mathrm{Fe}_{0.8} \mathrm{Bi}_{0.2} \mathrm{O}_{3-\delta}\end{array}$ & 0.1 & $\begin{array}{c}0.1 \% \text { toluene, } 40 \% \mathrm{O}_{2}, \mathrm{~N}_{2} \\
\text { balance, } 33.3 \mathrm{~mL} / \mathrm{min}\end{array}$ & 20000 & 147 & 220 & 242 & - & - & 45.9 & [99] \\
\hline $3 \mathrm{DOM} \mathrm{Eu}_{0.6} \mathrm{Sr}_{0.4} \mathrm{FeO}_{3}$ & 0.05 & $\begin{array}{c}0.1 \% \text { toluene, } 40 \% \mathrm{O}_{2}, \mathrm{~N}_{2} \\
\text { balance, } 33.3 \mathrm{~mL} / \mathrm{min}\end{array}$ & 20000 & 233 & 278 & 305 & $\begin{array}{c}0.0301 \\
\left(240^{\circ} \mathrm{C}\right)\end{array}$ & - & 81.1 & {$[100]$} \\
\hline $\begin{array}{l}3 \mathrm{wt} \% \mathrm{CoO}_{x} / 3 \mathrm{DOM} \\
\mathrm{Eu}_{0.6} \mathrm{Sr}_{0.4} \mathrm{FeO}_{3}\end{array}$ & 0.1 & $\begin{array}{l}0.1 \% \text { toluene, } 40 \% \mathrm{O}_{2}, \mathrm{~N}_{2} \\
\text { balance, } 33.3 \mathrm{~mL} / \mathrm{min}\end{array}$ & 20000 & 220 & 251 & 270 & $\begin{array}{c}0.0473 \\
\left(240^{\circ} \mathrm{C}\right)\end{array}$ & - & 72.3 & [101] \\
\hline $\begin{array}{l}8 \mathrm{wt} \% \mathrm{Co}_{3} \mathrm{O}_{4} / 3 \mathrm{DOM} \\
\mathrm{La}_{0.6} \mathrm{Sr}_{0.4} \mathrm{CoO}_{3}\end{array}$ & 0.1 & $\begin{array}{c}0.1 \% \text { toluene, } 40 \% \mathrm{O}_{2}, \mathrm{~N}_{2} \\
\text { balance, } 33.3 \mathrm{~mL} / \mathrm{min}\end{array}$ & 20000 & 158 & 210 & 227 & - & - & 43.3 & {$[102]$} \\
\hline $\begin{array}{l}4.9 \mathrm{wt} \% \mathrm{Au} / \text { chain-like } \\
\mathrm{LaMnO}_{3}\end{array}$ & 0.05 & $\begin{array}{c}0.1 \% \text { toluene, } 40 \% \mathrm{O}_{2}, \mathrm{~N}_{2} \\
\text { balance, } 16.7 \mathrm{~mL} / \mathrm{min}\end{array}$ & 20000 & 138 & 201 & 226 & - & $\begin{array}{c}2.80 \times 10^{-3} \\
\left(200^{\circ} \mathrm{C}\right)\end{array}$ & 47 & [103] \\
\hline $\begin{array}{l}12 \mathrm{wt} \% \mathrm{MnO}_{x} / 3 \mathrm{DOM} \\
\mathrm{LaMnO}_{3}\end{array}$ & 0.1 & $\begin{array}{l}0.1 \% \text { toluene, } 40 \% \mathrm{O}_{2}, \mathrm{~N}_{2} \\
\text { balance, } 33.3 \mathrm{~mL} / \mathrm{min}\end{array}$ & 20000 & 152 & 193 & 215 & $\begin{array}{c}0.0290 \\
\left(160^{\circ} \mathrm{C}\right)\end{array}$ & - & 61 & [37] \\
\hline $\begin{array}{l}\text { 7.63wt } \% \mathrm{Au} / 3 \mathrm{DOM} \\
\mathrm{LaCoO}_{3}\end{array}$ & 0.1 & $\begin{array}{l}0.1 \% \text { toluene, } 40 \% \mathrm{O}_{2}, \mathrm{~N}_{2} \\
\text { balance, } 33.3 \mathrm{~mL} / \mathrm{min}\end{array}$ & 20000 & 136 & 188 & 202 & - & $\begin{array}{c}1.04 \times 10^{-3} \\
\left(200^{\circ} \mathrm{C}\right)\end{array}$ & 31.4 & [104] \\
\hline $3 \mathrm{DOM} \mathrm{EuFeO}_{3}$ & $0.1-0.2$ & $\begin{array}{l}0.1 \% \text { toluene, } 40 \% \mathrm{O}_{2}, \mathrm{~N}_{2} \\
\text { balance, } 33.3 \mathrm{~mL} / \mathrm{min}\end{array}$ & 20000 & 254 & 312 & 347 & - & - & 82.0 & [105] \\
\hline $\begin{array}{l}5.92 \mathrm{wt} \% \mathrm{Au} / 8 \mathrm{wt} \% \mathrm{MnO}_{x} / \\
3 \mathrm{DOM} \mathrm{La}_{0.6} \mathrm{Sr}_{0.4} \mathrm{MnO}_{3}\end{array}$ & 0.05 & $\begin{array}{l}0.1 \% \text { toluene, } 40 \% \mathrm{O}_{2}, \mathrm{~N}_{2} \\
\text { balance, } 16.7 \mathrm{~mL} / \mathrm{min}\end{array}$ & 20000 & 160 & 205 & 220 & - & - & 52.8 & [106] \\
\hline $\begin{array}{l}\text { 1.67wt } \% \mathrm{Mn}_{3} \mathrm{O}_{4}-2 \mathrm{wt} \% \mathrm{Au} / \\
\text { 3DOM La } \mathrm{La}_{0.6} \mathrm{Sr}_{0.4} \mathrm{CoO}_{3}\end{array}$ & 0.05 & $\begin{array}{c}0.1 \% \text { toluene, } 40 \% \mathrm{O}_{2}, \mathrm{~N}_{2} \\
\text { balance, } 16.7 \mathrm{~mL} / \mathrm{min}\end{array}$ & 20000 & 164 & 214 & 230 & $\begin{array}{c}0.410 \\
\left(230^{\circ} \mathrm{C}\right)\end{array}$ & $\begin{array}{c}3.90 \times 10^{-3} \\
\left(230^{\circ} \mathrm{C}\right)\end{array}$ & 41.7 & [107] \\
\hline $\mathrm{MnO}_{2} / \mathrm{LaMnO}_{3}$ & 0.05 & $\begin{array}{c}0.2 \% \text { toluene, } 20 \% \mathrm{O}_{2}, \mathrm{~N}_{2} \\
\text { balance, } 100 \mathrm{~mL} / \mathrm{min}\end{array}$ & 120000 & - & 263 & 279 & - & - & 57 & [108] \\
\hline
\end{tabular}

sistent with the performances of bulk catalysts in the oxidation of NO and soot particulates [109-111]. However, the stabilities of the three salts under high temperature were in the opposite order [112]. Consequently, the manganates were widely researched in VOCs oxidation due to their moderate catalytic activity and stability.

Dai et al. $[38,94]$ did lots of valuable works on this topic together with his research partners. In 2011, they synthesized 3DOM $\mathrm{LaMnO}_{3}$ using PMMA CCT with the assistance of surfactants, such as PEG 400, P123 and L-lysine. The introduction of surfactants was favorable for the formation of mesoporous skeletons increased the surface area of $3 \mathrm{DOM} \mathrm{LaMnO}{ }_{3}$. These mesoporous 3DOM materials achieved notably enhanced catalytic activity for the combustion of toluene. It can also be found from these papers that the catalyst with the larger BET surface area exhibited the higher catalytic activity for toluene combustion, indicating that the active sites were mainly located at the inner surface of 3DOM $\mathrm{LaMnO}_{3}$ materials.

The oxidation of toluene usually occurs on the surface transition metal ion-sites (e.g. Mn cations) [113]. Therefore, the introduction of highly active manganese oxides promoted the exposure of $\mathrm{Mn}$ active sites and further improved the catalytic activity for toluene oxidation. For instance, 3DOM $\mathrm{LaMnO}_{3}$ supported $\mathrm{MnO}_{x}$ [37] was prepared via the in situ tryptophan-assisted PMMA-templating route which uniformly dispersed $\mathrm{MnO}_{x}$ nanoparticles on the surface of 3DOM LaMnO 3 . For both toluene and methanol combustion reaction, the 12 wt $\% \mathrm{MnO}_{x} / 3 \mathrm{DOM} \mathrm{LaMnO}_{3}$ exhibited enhanced catalytic performance compared with 3DOM $\mathrm{LaMnO}_{3}$ and $12 \mathrm{wt} \%$ $\mathrm{MnO}_{x} /$ bulk $\mathrm{LaMnO}_{3}$. These results can be attributed to the strong interaction between $\mathrm{MnO}_{x}$ and $3 \mathrm{DOM} \mathrm{LaMnO}$, as well as the increased adsorbed oxygen concentration and low-temperature reducibility. The similar $\mathrm{MnO}_{2} / \mathrm{LaMnO}_{3}$ catalysts were also prepared by $\mathrm{Si}$ et al. [108] through a facile one-step method, in which $3 \mathrm{DOM} \mathrm{LaMnO}_{3}$ was immersed in diluted $\mathrm{HNO}_{3}$ solution and the La cations were partially removed from perovskite structure, as shown in Fig. 4. After treatment with acid, the well-ordered structure of 3DOM $\mathrm{LaMnO}_{3}$ became disordered, but multiple nanopores appeared and the surface area increased. The obtained catalyst exhibited improved activity compared with 3DOM $\mathrm{LaMnO}_{3}$ for toluene combustion. This result indicates that the surface area and surface chemical properties of 3DOM perovskite catalysts are the crucial factors for toluene oxidation rather than the degree of 


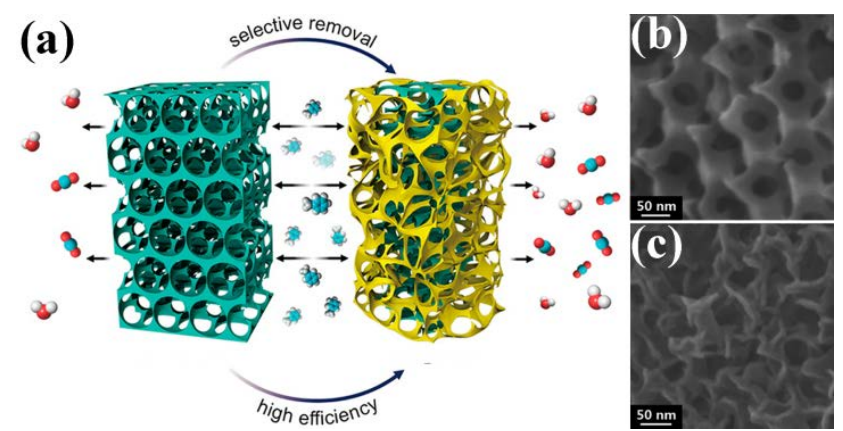

Fig. 4. (a) The synthesis of the $\mathrm{MnO}_{2} / \mathrm{LaMnO}_{3}$. The green structure is $\mathrm{LaMnO}_{3}$, and the yellow structure is $\mathrm{MnO}_{2}$. TEM images of 3DOM LaM$\mathrm{nO}_{3}$ (b) and $\mathrm{MnO}_{2} / \mathrm{LaMnO}_{3}$ (c). Reprinted from [108]. Copyright (2016) American Chemical Society.

\section{structural order of 3DOM skeletons.}

Another example to support this viewpoint is the disassembled 3DOM $\mathrm{LaMnO}_{3}$ as support for Au nanoparticles reported by Liu et al. [103]. Through a controlled calcination program, the $3 \mathrm{DOM} \mathrm{LaMnO}_{3}$ can be well dissociated into two-dimensionally chain-like building blocks as described in Fig. 5. Although the three-dimensionally ordered materials were reduced to the two-dimensionally ordered materials, the surface area of these chain-like materials might be slightly increased. After deposition of Au nanoparticles, the obtained 4.9 $\mathrm{wt} \% \mathrm{Au} / \mathrm{LaMnO}_{3}$ exhibited a high catalytic activity for the oxidation of $\mathrm{CO}$ and toluene. The higher surface area, better low-temperature reducibility and the strong metal-support interaction are attributed the enhanced catalytic performance.

Although ferrite perovskites have a slightly lower catalytic activity in toluene, 3DOM ferrite perovskites are still considered as the potential catalysts for practical application due to their good anti-poisoning capacity [114]. In the research on ferrite perovskites, the A-site cations can be either $\mathrm{Sr}[95,96]$, $\mathrm{Eu}$ [105], or a co-doping of La \& Sr [97] or Eu \& Sr [100]. The B-site cation Fe can also be partly substituted by Bi to produce catalyst 3DOM La0.6 $\mathrm{Sr}_{0.4} \mathrm{Fe}_{0.8} \mathrm{Bi}_{0.2} \mathrm{O}_{3-\delta}$ [99]. To improve the activity of the catalyst, the $\mathrm{CoO}_{x}$ was used as co-catalyst and dis-

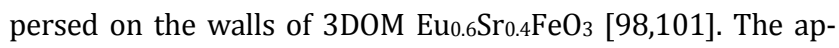

propriate amounts of $\mathrm{CoO}_{x}$ brought higher surface oxygen vacancy density, which absorbed and activated oxygen. As the result, the catalytic performance was benefited. For example, the specific reaction rate for toluene oxidation at $240{ }^{\circ} \mathrm{C}$ increased from 0.0301 to $0.0473 \mu \mathrm{mol} /\left(\mathrm{g}_{\text {cat }} \cdot \mathrm{s}\right)$ after decoration of $3 \mathrm{wt} \%$ of $\mathrm{CoO}_{x}$ on the surface of 3DOM Eu0.6 $\mathrm{Sr}_{0.4} \mathrm{FeO}_{3}$.

Similar to $\mathrm{Mn}$ and $\mathrm{Fe}$, the valence state variation of Co makes cobaltate perovskites suitable for catalytic oxidation of toluene. Dai and coworkers [102] investigated the catalytic performance of $\mathrm{Co}_{3} \mathrm{O}_{4} / 3 \mathrm{DOM} \mathrm{La} 0.6 \mathrm{Sr}_{0.4} \mathrm{CoO}_{3}, \mathrm{Au} / 3 \mathrm{DOM} \mathrm{LaCoO}_{3}$ [104] and $\mathrm{Mn}_{3} \mathrm{O}_{4}-\mathrm{Au} / 3 \mathrm{DOM} \mathrm{La}_{0.6} \mathrm{Sr}_{0.4} \mathrm{CoO}_{3}$ [107] for toluene combustion. Using a co-catalyst of metal oxide or noble metal, the cobaltate perovskite catalysts exhibited high catalytic performances. The $T_{90 \%}\left(202{ }^{\circ} \mathrm{C}\right)$ and the $E_{\mathrm{a}}(31.4 \mathrm{~kJ} / \mathrm{mol})$ for toluene oxidation were significantly lower than that of 3DOM manganate and ferrite perovskites catalysts [104].

In addition to the oxidation of toluene, 3DOM perovskites can also be applied in the catalytic elimination of other VOCs, such as 1,2-dichloroethane. Catalyzed by $\mathrm{Co}_{3} \mathrm{O}_{4} / 3 \mathrm{DOM}$ $\mathrm{La}_{0.7} \mathrm{Sr}_{0.3} \mathrm{Fe}_{0.5} \mathrm{Co}_{0.5} \mathrm{O}_{3}$ with mesopores [115], the dehydrochlorination and chlorination were enhanced due to the intimate contact between the reactant molecules and the chemisorbed oxygen species on the surface. With the better transportation and diffusion properties, $10 \quad w t \% \quad \mathrm{Co}_{3} \mathrm{O}_{4} / 3 \mathrm{DOM}$ $\mathrm{La}_{0.7} \mathrm{Sr}_{0.3} \mathrm{Fe}_{0.5} \mathrm{Co}_{0.5} \mathrm{O}_{3}$ with mesopores presented the lowest $E_{\mathrm{a}}$ $(22.6 \mathrm{~kJ} / \mathrm{mol})$ and highest reaction rate $\left(2.29 \times 10^{-11} \mathrm{~mol} /(\mathrm{g} \cdot \mathrm{s})\right)$ for 1,2-dichloroethane oxidation. The high chlorine poisoning tolerance and selectivity were shown to be advantages of the catalyst. Although only a limited number of VOCs are selected as target contaminants in this research field, the 3DOM perovskite materials with mesopores have demonstrated their huge potential in the catalytic elimination of VOCs.

In this part, various 3DOM perovskite materials were employed in the oxidation of VOCs and good catalytic performances were achieved. The introduction of transition metal oxides on 3DOM perovskite materials can additionally increase the active sites. With high dispersion of noble metal Au on perovskite surface, the hydrocarbon is activated more easily and lower $E_{\mathrm{a}}$ can be attained. Especially, the disassembled materials

\section{(a)}

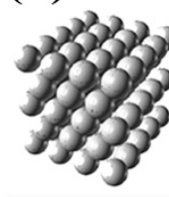

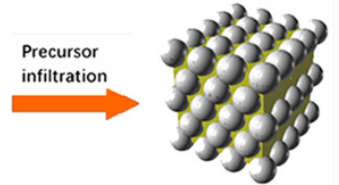

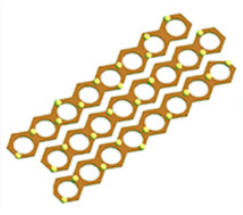

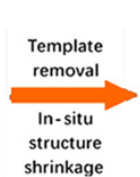
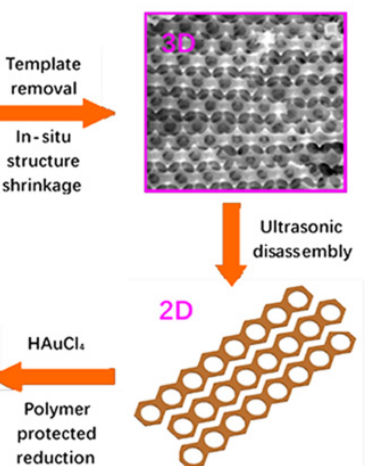
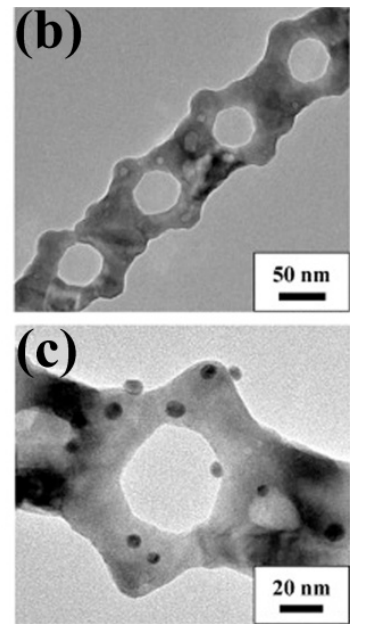

Fig. 5. (a) Schematic diagram of the preparation process of the chain-like $\mathrm{LaMnO}_{3}$ and $\mathrm{xAu} / \mathrm{LaMnO} \mathrm{S}_{3}$ samples; $\mathrm{TEM}$ images of chain-like ordered macroporous $\mathrm{LaMnO}_{3}$ (b) and $4.9 \mathrm{wt} \% \mathrm{Au} /$ chain-like ordered macroporous $\mathrm{LaMnO}_{3}$ (c). Reprinted from [103] with permission from Elsevier. 
behaved good activities in the catalytic elimination of VOCs, suggesting that the surface area and surface chemical constitution of 3DOM perovskite catalysts are the crucial factors for VOCs oxidation.

\subsection{Methane combustion}

Apart from $\mathrm{CO}_{2}$, unburned $\mathrm{CH}_{4}$, the major component of natural gas, is regarded as a highly problematic greenhouse gas [116-118]. Complete combustion of $\mathrm{CH}_{4}$ promoted by catalysts under a relatively low temperature could solve two problems at once by reducing emissions and making full use of energy from natural gas [119]. According to the Mars and van Krevelen mechanism (MvK mechanism) [120], the reaction pathway of methane combustion over perovskite catalysts is divided into three steps [121]: (1) gas phase $\mathrm{CH}_{4}$ adsorbs on the A-site of perovskite oxides; (2) adsorbed $\mathrm{CH}_{4}$ is attacked by surface lattice oxygen to form $\mathrm{CH}_{3}$, then continuously oxidized to form adsorbed $\mathrm{CO}_{2}$ and $\mathrm{H}_{2} \mathrm{O}$, accompanied by the generation of oxygen vacancies; (3) adsorbed $\mathrm{CO}_{2}$ and $\mathrm{H}_{2} \mathrm{O}$ desorb from the surface of catalysts to produce molecule $\mathrm{CO}_{2}$ and $\mathrm{H}_{2} \mathrm{O}$, and the oxygen vacancies are refilled with surface adsorbed oxygen. The cleavage of the first $\mathrm{C}-\mathrm{H}$ bond is considered as the rate-determining step for the catalytic combustion of methane [122]. The excellent ion mobility, redox property and thermal stability also make perovskite a good candidate for suitable catalysts [123]. The reactivity of lattice oxygen of perovskite oxides plays a crucial factor in methane combustion. In particular, partly substituting B-site cations with other elements can modify the redox properties to specifically enhance their catalytic activity [124]. As one kind of hierarchical porous structure, 3DOM structure can reduce the flow resistance and promote the contact between catalyst and reaction gases in the methane combustion $[125,126]$. The appropriate pore diameters, large surface area, abundant active sites and good mass transfer property of 3DOM structure are also favorable for the reaction $[127,128]$. Considering this, 3DOM perovskite materials are promising catalysts or catalyst supports in the methane combustion. The 3DOM perovskite catalysts used for methane combustion are listed in Table 3 . The temperatures of $T_{10 \%}$, $T_{50 \%}$ and $T_{90 \%}$ for methane conversion, specific reaction rates, TOF values, and $E_{\mathrm{a}}$ of these catalytic systems are also involved in Table 3.

Yuan et al. [129] reported that 3DOM $\mathrm{La}_{2} \mathrm{CuO}_{4}$, which belongs to the perovskite-like structure, was successfully synthesized in the presence of citric acid. It demonstrated the importance of incorporating an appropriate amount of citric acid in the preparation of 3DOM materials. The 3DOM $\mathrm{La}_{2} \mathrm{CuO}_{4}$ sample showed better low-temperature reducibility than the wormhole-like macroporous structured $\mathrm{La}_{2} \mathrm{CuO}_{4}$, which may be the reason for its higher catalytic activity in methane combustion.

It has been reported that the combustion of methane involves in the activation of $\mathrm{C}-\mathrm{H}$ bonds by active oxygen species $[130,131]$. Therefore the defect structure, pore structure, and surface area of a catalyst were regarded as important factors for the development of an efficient catalyst [129]. Arandiyan et al. [132] fabricated high-quality 3DOM $\mathrm{La}_{0.6} \mathrm{Sr}_{0.4} \mathrm{MnO}_{3}$ using nanovoids with appropriate amounts of DMOTEG and Pluronic P-123 assisted PMMA-templating route. In the reaction, $T_{10 \%}$, $T_{50 \%}$, and $T_{90 \%}$ of 3DOM La0.6 $\mathrm{Sr}_{0.4} \mathrm{MnO}_{3}$ were lower by 125,106 and $88{ }^{\circ} \mathrm{C}$ than those of bulk $\mathrm{La}_{0.6} \mathrm{Sr}_{0.4} \mathrm{MnO}_{3}$. The higher adsorbed oxygen species concentration, resulting from the higher concentration of surface oxygen vacancies, acted as a crucial component in the promoting of catalytic activity. In addition, the thermal stability of $3 \mathrm{DOM} \mathrm{La}_{0.6} \mathrm{Sr}_{0.4} \mathrm{MnO}_{3}$ was very good, with the 3DOM structure maintaining perfectly after being aged at $800{ }^{\circ} \mathrm{C}$. The $3 \mathrm{DOM} \mathrm{La1-x} \mathrm{Ce}_{x} \mathrm{CoO}_{3}$ with nanovoids were also synthesized through the similar method using CTAB and Pluronic P-123 as the surfactant [133].

Table 3

Summary of 3DOM perovskite catalysts for methane combustion.

\begin{tabular}{|c|c|c|c|c|c|c|c|c|c|c|}
\hline \multirow{2}{*}{ Catalyst } & \multirow{2}{*}{$\begin{array}{l}\text { Weight } \\
\text { (g) }\end{array}$} & \multirow{2}{*}{ Reactant feed } & \multirow{2}{*}{$\begin{array}{c}\text { Space } \\
\text { velocity } \\
(\mathrm{mL} /(\mathrm{g} \cdot \mathrm{h}))\end{array}$} & \multicolumn{3}{|c|}{ Methane conversion capacity } & \multirow{2}{*}{$\begin{array}{l}\text { Specific reac- } \\
\text { tion rate } \\
\left(\mu \mathrm{mol} /\left(\mathrm{g}_{\mathrm{cat}} \cdot \mathrm{s}\right)\right)\end{array}$} & \multirow{2}{*}{$\begin{array}{c}\text { TOF }_{\text {Noble Metal }} \\
\left(\mathrm{s}^{-1}\right)\end{array}$} & \multirow{2}{*}{$\begin{array}{c}E_{\mathrm{a}} \\
(\mathrm{kJ} / \mathrm{mol})\end{array}$} & \multirow{2}{*}{ Ref. } \\
\hline & & & & $T_{10 \%}\left({ }^{\circ} \mathrm{C}\right)$ & $T_{50 \%}\left({ }^{\circ} \mathrm{C}\right)$ & $T_{90 \%}\left({ }^{\circ} \mathrm{C}\right)$ & & & & \\
\hline $3 \mathrm{DOM} \mathrm{La}_{2} \mathrm{CuO}_{4}$ & 0.05 & $\begin{array}{c}2 \% \mathrm{CH}_{4}, 20 \% \mathrm{O}_{2}, \mathrm{~N}_{2} \\
\text { balance, } 41.6 \mathrm{~mL} / \mathrm{min}\end{array}$ & 50000 & - & 560 & 672 & $\begin{array}{l}\text { ca. } 11.1 \\
\left(672^{\circ} \mathrm{C}\right)\end{array}$ & - & - & [129] \\
\hline $\begin{array}{l}\text { 1.18wt } \% \mathrm{Pd} / 3 \mathrm{DOM} \\
\mathrm{La}_{0.6} \mathrm{Sr}_{0.4} \mathrm{MnO}_{3}\end{array}$ & 0.05 & $\begin{array}{l}0.5 \% \mathrm{CH}_{4}, 20 \% \mathrm{O}_{2}, \mathrm{~N}_{2} \\
\text { balance, } 33.3 \mathrm{~mL} / \mathrm{min}\end{array}$ & 40000 & 405 & 489 & 583 & $\begin{array}{c}0.09 \\
\left(350^{\circ} \mathrm{C}\right)\end{array}$ & - & - & [134] \\
\hline $3 \mathrm{DOM} \mathrm{La}_{0.6} \mathrm{Sr}_{0.4} \mathrm{MnO}_{3}$ & 0.02 & $\begin{array}{c}2 \% \mathrm{CH}_{4}, 20 \% \mathrm{O}_{2}, \mathrm{~N}_{2} \\
\text { balance, } 41.6 \mathrm{~mL} / \mathrm{min}\end{array}$ & 30000 & 437 & 566 & 661 & $\begin{array}{c}0.0143 \\
\left(300^{\circ} \mathrm{C}\right)\end{array}$ & - & 56.6 & [132] \\
\hline $\begin{array}{l}3.63 \mathrm{wt} \% \mathrm{Ag} / 3 \mathrm{DOM} \\
\mathrm{La}_{0.6} \mathrm{Sr}_{0.4} \mathrm{MnO}_{3}\end{array}$ & 0.02 & $\begin{array}{c}2 \% \mathrm{CH}_{4}, 20 \% \mathrm{O}_{2}, \mathrm{~N}_{2} \\
\text { balance, } 41.6 \mathrm{~mL} / \mathrm{min}\end{array}$ & 30000 & 361 & 454 & 524 & $\begin{array}{c}0.000351 \\
\left(300^{\circ} \mathrm{C}\right)\end{array}$ & $\begin{array}{c}1.86 \times 10^{-5} \\
\left(300^{\circ} \mathrm{C}\right)\end{array}$ & 37.5 & {$[135,136]$} \\
\hline $3 \mathrm{DOM} \mathrm{LaMn}_{0.97} \mathrm{Pd}_{0.03} \mathrm{O}_{3}$ & 0.05 & $\begin{array}{l}1 \% \mathrm{CH}_{4}, 17 \% \mathrm{O}_{2}, \mathrm{He} \\
\text { balance, } 30 \mathrm{~mL} / \mathrm{min}\end{array}$ & 32000 & 325 & 412 & 504 & 0.0252 a & - & 51.5 & [137] \\
\hline 3DOM-m La $0.7 \mathrm{Ce}_{0.3} \mathrm{CoO}_{3}$ & 0.02 & $\begin{array}{c}2 \% \mathrm{CH}_{4}, 20 \% \mathrm{O}_{2}, \mathrm{~N}_{2} \\
\text { balance, } 41.6 \mathrm{~mL} / \mathrm{min}\end{array}$ & 30000 & 381 & 479 & 555 & - & - & 53 & [133] \\
\hline $\begin{array}{l}\text { 3.0wt } \% \mathrm{Au}-\mathrm{Pd} / 3 \mathrm{DOM} \\
\mathrm{La}_{0.6} \mathrm{Sr}_{0.4} \mathrm{MnO}_{3}\end{array}$ & 0.02 & $\begin{array}{c}5 \% \mathrm{CH}_{4}, 30 \% \mathrm{O}_{2}, \mathrm{~N}_{2} \\
\text { balance, } 42.8 \mathrm{~mL} / \mathrm{min}\end{array}$ & 50000 & 280 & 331 & 354 & $\begin{array}{c}3.52 \\
\left(270^{\circ} \mathrm{C}\right)\end{array}$ & $\begin{array}{c}1.60 \times 10^{-2} \\
\left(270^{\circ} \mathrm{C}\right)\end{array}$ & 46.3 & {$[36]$} \\
\hline 3D-hm La $0.6 \mathrm{Sr}_{0.4} \mathrm{MnO}_{3}$ & 0.05 & $\begin{array}{c}5 \% \mathrm{CH}_{4}, 30 \% \mathrm{O}_{2}, \mathrm{~N}_{2} \\
\text { balance, } 42.8 \mathrm{~mL} / \mathrm{min}\end{array}$ & 50000 & 310 & 360 & 438 & $\begin{array}{c}11.2 \\
\left(350^{\circ} \mathrm{C}\right)\end{array}$ & - & 67.3 & [138] \\
\hline
\end{tabular}

a The unit of the datum is $\left[\mu \mathrm{mol}_{\mathrm{CH} 4} /\left(\mathrm{m}^{2}{ }_{\mathrm{cat}} \cdot \mathrm{s}\right)\right]$. 
To further improve on the catalytic activity, different kinds of noble metal nanoparticles, such as Pd [134], Ag [135,136] and Au-Pd alloy [36], were loaded on 3DOM La0.6Sro.4MnO 3 with mesopores. After loading noble metals on 3DOM perovskites, the conversion temperature of methane and the $E_{\mathrm{a}}$ obviously decrease as shown in Table 3. Among these catalysts, the bimetallic $3.0 \mathrm{wt} \% \mathrm{Au}-\mathrm{Pd} / 3 \mathrm{DOM} \mathrm{La} \mathrm{La}_{6} \mathrm{Sr}_{0.4} \mathrm{MnO}_{3}$ [36] performed the best, giving $T_{10 \%}, T_{50 \%}$ and $T_{90 \%}$ of 280,331 , and $354{ }^{\circ} \mathrm{C}$, respectively. The $\mathrm{TOF}_{\mathrm{Au}-\mathrm{Pd}}\left(1.60 \times 10^{-2} \mathrm{~s}^{-1}\right.$ at $\left.270^{\circ} \mathrm{C}\right)$ was higher than other catalyst as well. Importantly, according to in situ diffuse reflectance infrared Fourier transform spectroscopy (DRIFTS) spectra as depicted in Fig. 6(a), $\mathrm{CH}_{3}{ }^{-}$species (1300 $\mathrm{cm}^{-1}$ ) emerged at $200{ }^{\circ} \mathrm{C}$ over $\mathrm{Au}-\mathrm{Pd} / 3 \mathrm{DOM} \mathrm{La}_{0.6} \mathrm{Sr}_{0.4} \mathrm{MnO}_{3}$ while at $300{ }^{\circ} \mathrm{C}$ over $\mathrm{Pd} / 3 \mathrm{DOM} \mathrm{La}{ }_{0.6} \mathrm{Sr}_{0.4} \mathrm{MnO}_{3}$. Moreover, almost all the methane ( 1300 and $3014 \mathrm{~cm}^{-1}$ ) was converted to $\mathrm{CO}_{2}$ (2330 and $2360 \mathrm{~cm}^{-1}$ ) at $550{ }^{\circ} \mathrm{C}$ for $\mathrm{Au}-\mathrm{Pd} / 3 \mathrm{DOM}$ $\mathrm{La}_{0.6} \mathrm{Sr}_{0.4} \mathrm{MnO}_{3}$, indicating the enhanced low-temperature conversion ability of adding $\mathrm{Au}$. In the detailed discussion of the mechanism in the reaction as described in Fig. 6(b), it was found that the presence of $\mathrm{Au}$ in the bimetallic catalyst modified the electronic distribution on the surface of the catalyst and changed the reaction pathway. In addition, Au weakened the bonding strength of important chemical intermediates and the Pd atoms, resulting in the intensification of the adsorbed oxygen species on the surface of the catalyst. In summary, contact between the metals and the support, as well as oxidized noble metal species on the surface were responsible for the

(a)
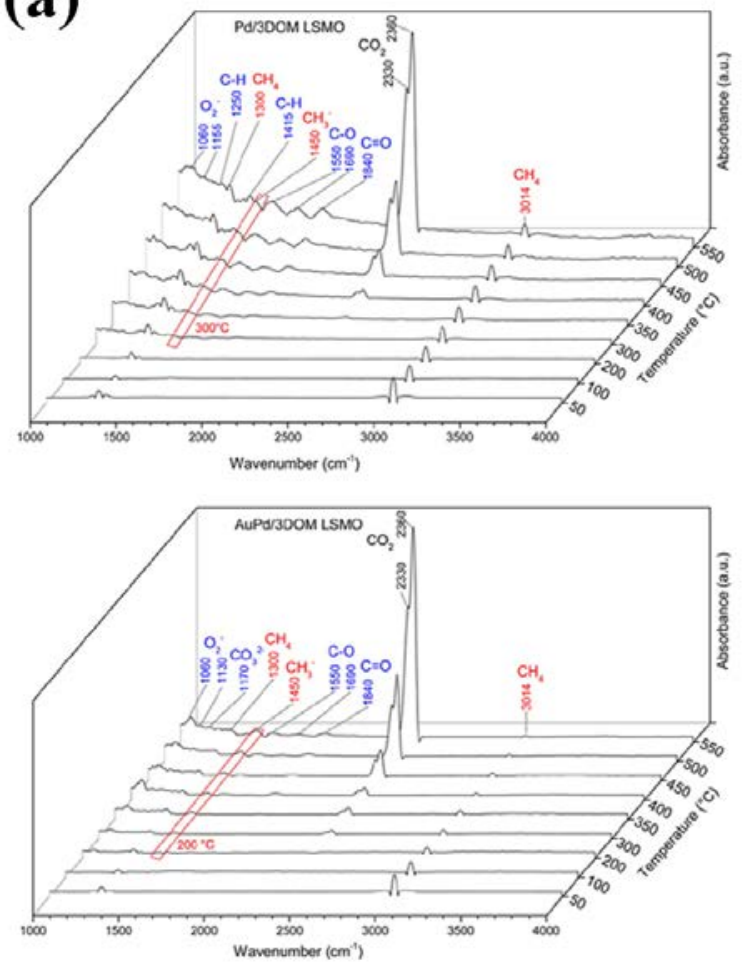

enhanced activity.

Changing exposed crystal facet is another effective strategy to accelerate the reaction rate. On the basis of 3DOM $\mathrm{La}_{0.6} \mathrm{Sr}_{0.4} \mathrm{MnO}_{3}$, the 3D hexapod mesostructured (3D-hm) $\mathrm{La}_{0.6} \mathrm{Sr}_{0.4} \mathrm{MnO}_{3}$ was prepared by Amal et al. [138] using ultrasonic method to cleave the weak connection points within the 3DOM framework as shown in Fig. 6(c). Both experimental results and density functional theory (DFT) calculations proved that, compared to the (110) facet of 3DOM catalyst, the newly exposed (001) facet of 3D-hm catalyst required lower energy to break the $\mathrm{C}-\mathrm{H}$ bond of $\mathrm{CH}_{4}$. The catalytic performance was highly efficient, the specific reaction rate was $11.2 \mu \mathrm{mol} /\left(\mathrm{g}_{\mathrm{cat}} \cdot \mathrm{s}\right)$ at $350{ }^{\circ} \mathrm{C}$. It proved the feasibility of using structural disassembly method to synthesize nanostructure with specified crystal facet exposed. This method is expected to be used not only in catalytic combustion but also in other fields.

In conclusion, almost all the 3DOM perovskite materials in this part are doped or partly substituted in B-sites to attain more surface adsorbed oxygen. It has been reported that the asymmetric and unsaturated coordination environment of lattice oxygen in oxide materials can significantly enhance the reactivity of lattice oxygen in redox reactions and obtain more efficient active sites in methane combustion [139]. Moreover, the decoration of noble metals on the surface of 3DOM perovskites can accelerate the fracture of the first $\mathrm{C}-\mathrm{H}$ bond in $\mathrm{CH}_{4}$ and decrease the conversion temperature of methane and the $E$ a. However, the durability of 3DOM materials under practical (b)

Proposed Reaction Pathway of Methane Oxidation over Au-Pd/3DOM LSMO

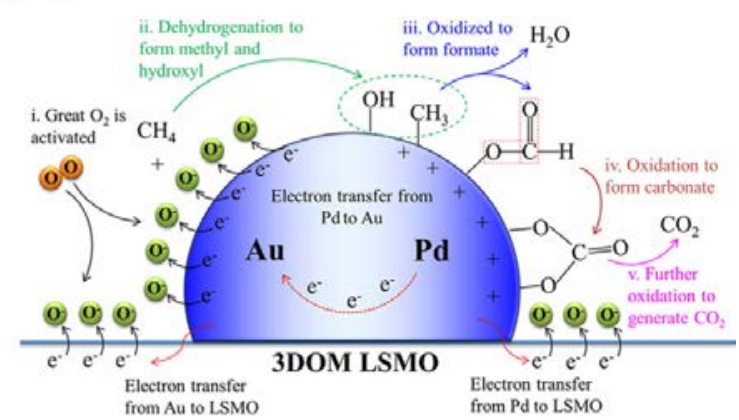

(c)

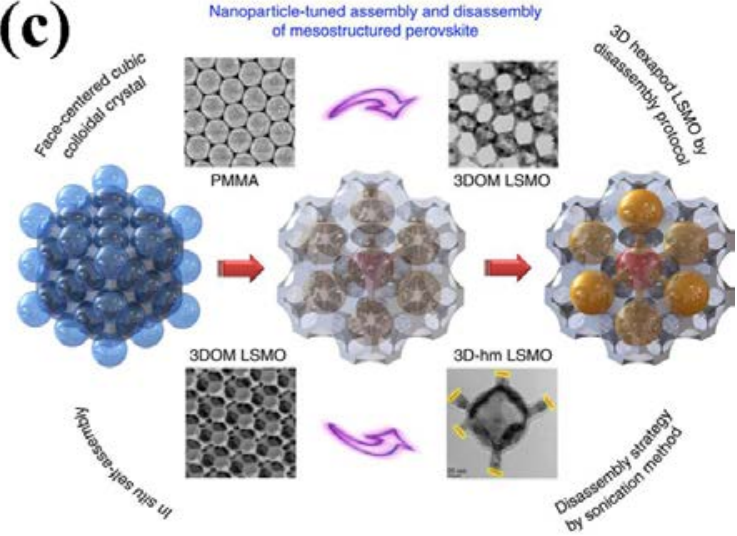

Fig. 6. (a) In situ DRIFT spectra of methane oxidation over Pd/3DOM La0.6Sro.4 $\mathrm{MnO}_{3}$ (marked as $\mathrm{Pd} / 3 \mathrm{DOM} \mathrm{LSMO}$ ) and $\mathrm{Au}-\mathrm{Pd} / 3 \mathrm{DOM} \mathrm{La} 0.6 \mathrm{Sr} \mathrm{AM}_{4} \mathrm{MnO}{ }_{3}$ (marked as AuPd/3DOM LSMO). (b) Proposed steps in the oxidation of methane over Au-Pd/3DOM La0.6 $\mathrm{Sr}_{0.4} \mathrm{MnO}_{3}$. Reprinted from [36]. Copyright (2016) American Chemical Society. (c) Schematic illustration of the synthesis process of 3D-hm $\mathrm{La}_{0.6} \mathrm{Sr}_{0.4} \mathrm{MnO}_{3}$. Reprinted from [138] with permission from Nature. 
application conditions is still an issue.

\subsection{Carbon dioxide methanation}

Apart from the applications mentioned aforesaid, 3DOM perovskite materials can be used in $\mathrm{CO}_{2}$ methanation reaction, which is the initial step of $\mathrm{CO}_{2}$ hydrogenation for the acquisition of value-added chemicals and is regarded as a potential strategy to solve the $\mathrm{CO}_{2}$-relevant environmental problems [140].

Arandiyan et al. [141] fabricated Rh-Ni alloys on 3DOM $\mathrm{LaAlO}_{3}$ with voids of c.a. 30-40 nm by in situ exsolution of $\mathrm{Ni}$ from 3DOM LaAl ${ }_{0.92} \mathrm{Ni}_{0.08} \mathrm{O}_{3}$ and followed by the in situ growth of Rh-Ni nanoalloys on both external and internal surfaces of 3DOM perovskite. In the $\mathrm{CO}_{2}$ methanation reaction, compared with the conventional catalyst $\mathrm{Rh} / 3 \mathrm{DOM} \mathrm{LaNi}_{0.08} \mathrm{Al}_{0.92} \mathrm{O}_{3}$, the $\mathrm{Rh}-\mathrm{Ni} / 3 \mathrm{DOM} \mathrm{LaAlO}_{3}$ catalyst showed a $52 \%$ higher turnover frequency. The hierarchically porous structure of the 3DOM perovskite support provided a high dispersion of bimetallic $\mathrm{Rh}-\mathrm{Ni}$ nanoparticles. The richness of basic sites and the surface adsorbed oxygen species are important to the adsorption of $\mathrm{CO}_{2}$, which is the key factor in the $\mathrm{CO}_{2}$ methanation process as well. This work provided a promising catalyst design pathway for preparing highly dispersed bimetallic catalysts on perovskites as well as a good reference for the conversion and utilization of $\mathrm{CO}_{2}$ using $3 \mathrm{DOM}$ perovskite materials.

\subsection{Sensors}

Sensors, which can detect and monitor toxic, hazardous or combustible gases or liquids, play crucial roles in safety supervision and environmental protection. In bulk materials, sensing reaction occurs only near the surface, and the inner part is inactive. However, with the large surface area as well as the uniform and ordered macropores [142-144], the target gas or liquid can diffuse into both the surface and the inner regions of 3DOM materials, which is beneficial for its utilization as sensing materials [145]. In addition, perovskites can express high responses and are stable at high temperatures, which are suitable for gas or liquid sensors [146,147].

Qin et al. synthesized 3DOM $\mathrm{LaFeO}_{3}$ [145] and 3DOM $\mathrm{La}_{1-x} \mathrm{Mg}_{x} \mathrm{FeO}_{3}$ [148] and used them as the gas sensors for methanol. As a p-type semiconductor, the conductivity of the materials depended on the presence of holes. When the sensor was exposed to air, electrons from the conduction band would be trapped by $\mathrm{O}_{2}$ adsorbed on the surface of the sample due to the strong electronegativity of oxygen and produced adsorbed oxygen. Therefore, the concentration of the holes increased and the electric resistance decreased. During oxygen absorption on the surface of the semiconductors, Eq. (3) may occur. While reducing methanol gas was introduced, Eq (4) occurred.

$$
\begin{aligned}
& \mathrm{O}_{2}(\mathrm{~g}) \leftrightharpoons \mathrm{O}_{2}^{-}(\mathrm{ad}) \leftrightharpoons \mathrm{O}^{-}(\mathrm{ad}) \leftrightharpoons \mathrm{O}^{2-}(\mathrm{ad}) \\
& \mathrm{CH}_{3} \mathrm{OH} \text { (gas) }+3 \mathrm{O}^{n-}(\mathrm{ad})=\mathrm{CO}_{2}(\mathrm{ad})+2 \mathrm{H}_{2} \mathrm{O}(\mathrm{ad})+3 \mathrm{ne}^{-}
\end{aligned}
$$

After the gas sensor was exposed to a methanol gas environment, a large number of electrons were released. As the consequence, the concentration of holes in the system decreased and the electrical resistance of the sensor increased. By monitoring the electric resistance, the methanol concentration was obtained. The responses of materials to methanol were donated by $R_{\mathrm{g}} / R_{\mathrm{a}}$, where $R_{\mathrm{g}}$ and $R_{\mathrm{a}}$ represented the resistance of sensor in air and methanol, respectively. The response time represented the time that the variation in electrical resistance to reach $90 \%$ of the equilibrium value after injecting methanol, and the recovery time indicated the time that the sensor returned to $90 \%$ above the original resistance in air. With the large surface area and the uniform macropores of the 3DOM structure, more surface-active sites were exposed for both oxygen adsorption and surface reactions, resulting in enhanced gas sensing property of the materials. Moreover, in contrast with ethanol or acetone, the samples exhibited good selectivity to methanol. In $3 \mathrm{DOM} \mathrm{La} \mathrm{La}_{1-x} \mathrm{Mg}_{x} \mathrm{FeO}_{3}$ material, to reconstruct the charge neutrality, oxygen vacancies were formed which acted as the centers of the positive charges [149]. The electrons around oxygen vacancies can be excited to the conduction band easily. Consequently, the sensing performance of the $\mathrm{Mg}^{2+}$ doped sample for methanol gas was better than the pristine sample, as described in Table 4.

Apart from methanol sensing, 3DOM perovskite can also work as $\mathrm{H}_{2} \mathrm{O}_{2}$ sensor as shown with $3 \mathrm{DOM} \mathrm{SmCoO}_{3}$, which was fabricated by He et al. [150]. In the chronoamperometric test at $0.35 \mathrm{~V}$ (the oxidation peak potential measured by cyclic voltammetry), the electrode with $3 \mathrm{DOM} \mathrm{SmCoO}_{3}$ displayed the fastest response ( $4 \mathrm{~s}$ ) to the change of $\mathrm{H}_{2} \mathrm{O}_{2}$ concentration. This mechanism can be explained by the valence state variation of Co, as shown in Fig. 7(a). In the first step, $\mathrm{Co}^{3+}$ was oxidized to $\mathrm{Co}^{4+}$ by releasing $\mathrm{H}^{+}$, which reacted with $\mathrm{OH}^{-}$to form water. In the second step, $\mathrm{Co}^{4+}$ was reduced to $\mathrm{Co}^{3+}$ by obtaining $\mathrm{H}^{+}$, and $\mathrm{OH}^{-}$was generated. Fig. 7(b) illustrates the overall processes, including diffusion, adsorption, electrooxidation and desorption steps. The 3DOM sample performed better for $\mathrm{H}_{2} \mathrm{O}_{2}$ electrooxidation, with higher sensitivity, higher selectivity, lower limit of detection and noise, as well as wider linear ranges. This should be ascribed to the larger surface area of the 3DOM materials, enabling faster electron transfer kinetics and diffusion rate.

\section{Conclusions and perspectives}

The unique structures and the versatile features of 3DOM

Table 4

\begin{tabular}{|c|c|c|c|c|c|}
\hline Material & Gas concentration/ Optimal temperature & Temperature range $\left({ }^{\circ} \mathrm{C}\right)$ & Response $\left(R_{\mathrm{g}} / R_{\mathrm{a}}\right)$ & $\begin{array}{c}\text { Response time/Recovery time } \\
(\mathrm{s} / \mathrm{s})\end{array}$ & Ref. \\
\hline 3DOM LaFeO ${ }_{3}$ & \multirow{2}{*}{$0.01 \% / 190^{\circ} \mathrm{C}$} & $150-300$ & 96 & $25 / 23$ & {$[145]$} \\
\hline 3DOM La $0.95 \mathrm{Mg}_{0.05} \mathrm{FeO}_{3}$ & & $150-280$ & 146.5 & $17.7 / 25.4$ & [148] \\
\hline
\end{tabular}

The responses of 3DOM $\mathrm{LaFeO}_{3}$ and $3 \mathrm{DOM} \mathrm{La} \mathrm{L}_{0.95} \mathrm{Mg}_{0.05} \mathrm{FeO}_{3}$ as methanol sensors. 
(a)

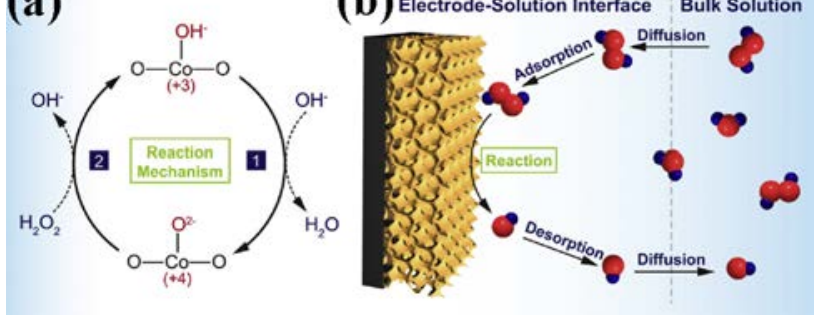

Fig. 7. (a) Electrooxidation mechanism of the reaction; (b) Reaction processes on the electrode. Reprinted from [150] with permission from Elsevier.

perovskites have attracted the interest of many scientists and made these materials widely applied in environmental fields. After years of exploration, many kinds of 3DOM perovskite materials were synthesized by CCT method. Under the assistance of surfactants, 3DOM perovskite materials with mesoporous skeletons can be successfully synthesized. Moreover, the disassembling of 3DOM materials can also fabricate novel nanostructures, such as chain-like and hexapod-like nanostructures. For different application fields, some common strategies of 3DOM perovskites exist, such as tailoring the cations in A-/B-sites and surface modification, which has been widely employed and systematically investigated. Fortunately, ca. $90 \%$ elements in the periodic table can be involved in perovskite materials and are waiting to be tested. As the consequence, theoretical prediction by DFT and high throughput material genome were developed to guide people for designing better materials rationally. However, the research focus should be very different for various reaction systems.

In photocatalysis, the slow photon effect of 3DOM structure can improve light utilization efficiency. Thus, for promoting photocatalytic activity, the order of the 3DOM structure and the location of the slow photon regions should be the crucial factors. For soot combustion reaction, due to the large size of soot particles, contact between soot particles and active sites is the key factor of soot combustion. Therefore, the average pore diameter of the macropores, especially the window size of the 3DOM materials plays a more important role compared to other reaction systems. For the combustion of VOCs and methane, the surface area of the 3DOM materials plays a crucial role because of the relatively smaller size of the target molecules. In this situation, 3DOM materials with mesoporous skeletons become the preferred choice.

To date however, no report suggests 3DOM perovskite materials have been used in practical applications. With complicated fabrication and unsatisfactory stability to blame. Therefore, the facile method for large-scale preparation of 3DOM materials should be further investigated. In addition, the crystal nucleation and the growth mechanism in the formation of skeletons of different 3DOM perovskite materials are still far from clear. It is important for researchers to focus on the fabrication of new kinds of 3DOM perovskites and the modification of surface structures and properties of these materials. In conclusion, there is still a long way to go in order to make 3DOM perovskite materials available for practical utilization and efforts should be made in order to create and study highly active 3DOM perovskite materials.

\section{Acknowledgments}

We thank Mr. Ethan Jarvis for English language editing. This work was supported by the Tianjin Municipal Natural Science Foundation (17JCYBJC22600) and the Fundamental Research Funds for the Central Universities.

\section{References}

[1] G. Liu, J. Li, J. Fu, G. Jiang, G. Lui, D. Luo, Y. P. Deng, J. Zhang, Z.P. Cano, A. Yu, D. Su, Z. Bai, L. Yang, Z. Chen, Adv. Mater., 2019, 31, e1806761.

[2] V. Alcalde-Santiago, A. Davó-Quiñonero, D. Lozano-Castelló, A. Bueno-López, Appl. Catal. B, 2018, 234, 187-197.

\section{Graphical Abstract}

Chin. J. Catal., 2019, 40: 1324-1338 doi: S1872-2067(19)63341-3

\section{Three-dimensionally ordered macroporous perovskite materials for environmental applications}

Chenxi Zhang, Peiyuan Zhao, Shuangxi Liu, Kai Yu*

Nankai University, China; University of New Hampshire, USA

The applications of three-dimensionally ordered macroporous perovskite materials in environmental fields are summarized, including photocatalysis, soot combustion, oxidation of volatile organic compounds, carbon dioxide methanation and sensors for gas or liquid. The materials present a good performance owing to the properties, such as slow photon effect, strong mass transfer ability, high surface area and adjustable composition.

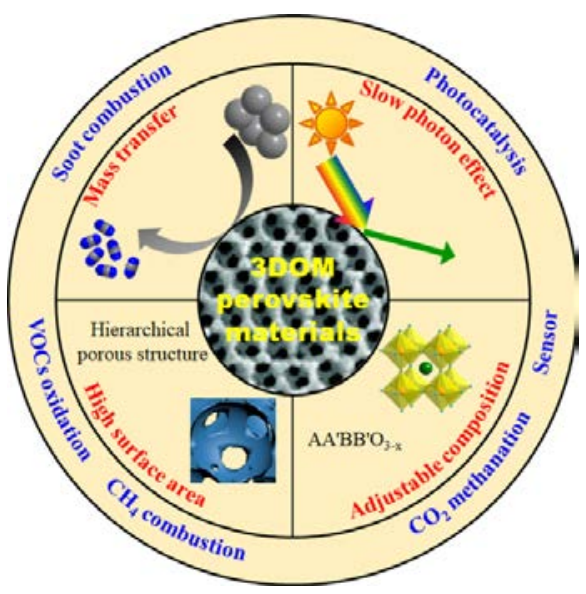


[3] Q. Wu, M. Jing, Y. Wei, Z. Zhao, X. Zhang, J. Xiong, J. Liu, W. Song, J. Li, Appl. Catal. B, 2019, 244, 628-640.

[4] B. Lin, J. Li, B. Xu, X. Yan, B. Yang, J. Wei, G. Yang, Appl. Catal. B, 2019, 243, 94-105

[5] A. Stein, B.E. Wilson, S.G. Rudisill, Chem. Soc. Rev., 2013, 42, 2763-2803.

[6] N. D. Petkovich, A. Stein, Chem. Soc. Rev., 2013, 42, 3721-3739.

[7] K. I. Kobayashi, T. Kimura, H. Sawada, K. Terakura, Y. Tokura, Nature, 1998, 395, 677-680.

[8] J. Zhu, Z. Zhao, D. Xiao, J. Li, X. Yang, Y. Wu, Ind. Eng. Chem. Res., 2005, 44, 4227-4233.

[9] Y. Zhu, G. Chen, N. Ma, W. Zhou, Z. Shao, Y. Zhong, Y. Chen, Nat. Commun., 2018, 9, 2326.

[10] M. Murakami, K. Hirose, K. Kawamura, N. Sata, Y. Ohishi, Science, 2004, 304, 855-858.

[11] L. H. Ni, Y. Liu, Z. H. Ren, X. Li, G. Xu, C. L. Song, G. R. Han, J. Appl. Phys., 2011, 110, 063506 .

[12] J. Zhu, A. Thomas, Appl. Catal. B, 2009, 92, 225-233.

[13] J. Zhu, H. Li, L. Zhong, P. Xiao, X. Xu, X. Yang, Z. Zhao, J. Li, ACS Catal., 2014, 4, 2917-2940.

[14] G. Zhang, G. Liu, L. Wang, J. T. Irvine, Chem. Soc. Rev., 2016, 45, 5951-5984.

[15] E. Grabowska, Appl. Catal. B, 2016, 186, 97-126.

[16] Y. Zhu, W. Zhou, Z. Shao, Small, 2017, 13, 1603793.

[17] H. Arandiyan, Y. Wang, H. Sun, M. Rezaei, H. Dai, Chem. Commun., 2018, 54, 6484-6502.

[18] Y. N. Kim, S. J. Kim, E. K. Lee, E. O. Chi, N. H. Hur, C. S. Hong, J. Mater. Chem., 2004, 14, 1774-1777.

[19] M. Sadakane, C. Takahashi, N. Kato, T. Asanuma, H. Ogihara, W. Ueda, Chem. Lett., 2006, 35, 480-481.

[20] A. Stein, F. Li, N.R. Denny, Chem. Mater., 2008, 20, 649-666.

[21] J. Fang, Y. Xuan, Q. Li, Chin. Sci. Bull., 2011, 56, 2156-2161.

[22] B.T. Holland, C.F. Blanford, T. Do, A. Stein, Chem. Mater., 1999, 11, 795-805.

[23] C. Dionigi, P. Nozar, D. Di Domenico, G. Calestani, J. Colloid Interface Sci., 2004, 275, 445-449.

[24] W. Stöber, A. Fink, E. Bohn, J. Colloid Interface Sci., 1968, 26, 62-69.

[25] G. H. Bogush, M. A. Tracy, C. F. Zukoski Iv, J. Non-Cryst. Solids, 1988, 104, 95-106.

[26] M. Sadakane, T. Asanuma, J. Kubo, W. Ueda, Chem. Mater., 2005, 17, 3546-3551.

[27] M. Sadakane, T. Horiuchi, N. Kato, C. Takahashi, W. Ueda, Chem. Mater., 2007, 19, 5779-5785.

[28] J. Zhu, M. Li, R. Rogers, W. Meyer, R. H. Ottewill, W. B. Russel, P. M. Chaikin, S. T. S .S. S. Crew, Nature, 1997, 387, 883-885.

[29] H. Míguez, F. Meseguer, C. López, Á. Blanco, J. S. Moya, J. Requena, A. Mifsud, V. Fornés, Adv. Mater., 1998, 10, 480-483.

[30] R. C. Schroden, M. Al-Daous, C. F. Blanford, A. Stein, Chem. Mater., 2002, 14, 3305-3315.

[31] M. Holgado, F. Garcia-Santamaria, A. Blanco, M. Ibisate, A. Cintas, H. Miguez, C. J. Serna, C. J. Molpeceres, J. Requena, A. Mifsud, C. Lopez, Langmuir, 1999, 15, 4701-4704.

[32] S. H. Park, D. Qin, Y. Xia, Adv. Mater., 1998, 10, 1028-1032.

[33] B. Gates, D. Qin, Y. Xia, Adv. Mater., 1999, 11, 466-469.

[34] M. Sadakane, C. Takahashi, N. Kato, H. Ogihara, Y. Nodasaka, Y. Doi, Y. Hinatsu, W. Ueda, Bull. Chem. Soc. Jpn., 2007, 80, 677-685.

[35] M. Sadakane, K. Sasaki, H. Nakamura, T. Yamamoto, W. Ninomiya, W. Ueda, Langmuir, 2012, 28, 17766-17770.

[36] Y. Wang, H. Arandiyan, J. Scott, M. Akia, H. Dai, J. Deng, K.-F. Aguey-Zinsou, R. Amal, ACS Catal., 2016, 6, 6935-6947.

[37] Y. Liu, H. Dai, J. Deng, Y. Du, X. Li, Z. Zhao, Y. Wang, B. Gao, H. Yang,
G. Guo, Appl. Catal. B, 2013, 140-141, 493-505.

[38] Y. Liu, H. Dai, Y. Du, J. Deng, L. Zhang, Z. Zhao, C.T. Au, J. Catal., 2012, 287, 149-160.

[39] J. Liu, H. Zhao, M. Wu, B. Van der Schueren, Y. Li, O. Deparis, J. Ye, G. A. Ozin, T. Hasan, B. L. Su, Adv. Mater., 2017, 29, 1605349.

[40] M. H. Sun, S. Z. Huang, L. H. Chen, Y. Li, X. Y. Yang, Z. Y. Yuan, B. L. Su, Chem. Soc. Rev., 2016, 45, 3479-3563.

[41] X. Zheng, Y. Yang, S. Chen, L. Zhang, Chin. J. Catal., 2018, 39, 379-389.

[42] S. Nishimura, N. Abrams, B. A. Lewis, L. I. Halaoui, T. E. Mallouk, K. D. Benkstein, J. van de Lagemaat, A. J. Frank, J. Am. Chem. Soc., 2003, 125, 6306-6310.

[43] J. I. L. Chen, G. von Freymann, S. Y. Choi, V. Kitaev, G. A. Ozin, Adv. Mater., 2006, 18, 1915-1919.

[44] O. Deparis, S. R. Mouchet, B. L. Su, Phys. Chem. Chem. Phys., 2015, 17, 30525-30532.

[45] H. Zhao, Z. Hu, J. Liu, Y. Li, M. Wu, G. Van Tendeloo, B.-L. Su, Nano Energy, 2018, 47, 266-274.

[46] S. Sun, W. Wang, L. Zhang, J. Mater. Chem., 2012, 22, 19244-19249.

[47] M. N. Ha, G. Lu, Z. Liu, L. Wang, Z. Zhao, J. Mater. Chem. A, 2016, 4, 13155-13165.

[48] X. Chen, J. Ye, S. Ouyang, T. Kako, Z. Li, Z. Zou, ACS Nano, 2011, 5, 4310-4318.

[49] Y. Chang, K. Yu, C. Zhang, R. Li, P. Zhao, L. L. Lou, S. Liu, Appl. Catal. $B$, 2015, 176, 363-373.

[50] K. Yu, C. Zhang, Y. Chang, Y. Feng, Z. Yang, T. Yang, L. L. Lou, S. Liu, Appl. Catal. B, 2017, 200, 514-520.

[51] Y. Chang, K. Yu, C. Zhang, Z. Yang, Y. Feng, H. Hao, Y. Jiang, L. L. Lou, W. Zhou, S. Liu, Appl. Catal. B, 2017, 215, 74-84.

[52] C. Zhang, K. Yu, Y. Feng, Y. Chang, T. Yang, Y. Xuan, D. Lei, L. L. Lou, S. Liu, Appl. Catal. B, 2017, 210, 77-87.

[53] Y. Chang, Y. Xuan, C. Zhang, H. Hao, K. Yu, S. Liu, Catal. Today, 2019, 327, 315-322.

[54] M. Antiñolo, M. D. Willis, S. Zhou, J. P. D. Abbatt, Nat. Commun., 2015, 6, 6812.

[55] R. A. Kerr, Science, 2013, 339, 382-382.

[56] Y. Chen, C. Du, Y. Lang, L. Jia, R. Chen, B. Shan, Catal. Sci. Technol., 2018, 8, 5955-5962.

[57] J. Liu, Z. Zhao, C. M. Xu, A. J. Duan, G. Y. Jiang, J. Phys. Chem. C, 2008 112, 5930-5941.

[58] W. Y. Hernández, D. Lopez-Gonzalez, S. Ntais, C. Zhao, A. Boréave, P. Vernoux, Appl. Catal. B, 2018, 226, 202-212.

[59] F. Fang, N. Feng, L. Wang, J. Meng, G. Liu, P. Zhao, P. Gao, J. Ding, H. Wan, G. Guan, Appl. Catal. B, 2018, 236, 184-194.

[60] B. R. Stanmore, J. F. Brilhac, P. Gilot, Carbon, 2001, 39, 2247-2268.

[61] B. Jin, Y. Wei, Z. Zhao, J. Liu, Y. Li, R. Li, A. Duan, G. Jiang, Chin. J. Catal., 2017, 38, 1629-1641.

[62] Y. Wei, Q. Wu, J. Xiong, J. Liu, Z. Zhao, Chin. J. Catal., 2018, 39, 606-612.

[63] C. Rao, R. Liu, X. Feng, J. Shen, H. Peng, X. Xu, X. Fang, J. Liu, X. Wang, Chin. J. Catal., 2018, 39, 1683-1694.

[64] M. Sadakane, T. Horiuchi, N. Kato, K. Sasaki, W. Ueda, J. Solid State Chem., 2010, 183, 1365-1371.

[65] J. Xu, J. Liu, Z. Zhao, G. Zhang, A. Duan, G. Jiang, C. Xu, Chin. J. Catal., 2010, 31, 236-241.

[66] J. Xu, J. Liu, Z. Zhao, J. Zheng, G. Zhang, A. Duan, G. Jiang, Catal. Today, 2010, 153, 136-142.

[67] Y. Wei, J. Liu, Z. Zhao, Y. Chen, C. Xu, A. Duan, G. Jiang, H. He, Angew. Chem. Int. Ed., 2011, 50, 2326-2329.

[68] J. Xu, J. Liu, Z. Zhao, C. Xu, J. Zheng, A. Duan, G. Jiang, J. Catal., 2011, $282,1-12$. 
[69] J. Zheng, J. Liu, Z. Zhao, J. Xu, A. Duan, G. Jiang, Catal. Today, 2012, 191, 146-153.

[70] Y. Wei, Z. Zhao, J. Jiao, J. Liu, A. Duan, G. Jiang, Catal. Today, 2015, 245, 37-45.

[71] L. Tang, Z. Zhao, Y. Wei, J. Liu, Y. Peng, K. Li, Catal. Today, 2017, 297, 131-142.

[72] N. Feng, Y. Wu, J. Meng, C. Chen, L. Wang, H. Wan, G. Guan, RSC Adv., 2015, 5, 91609-91618.

[73] N. Feng, J. Meng, Y. Wu, C. Chen, L. Wang, L. Gao, H. Wan, G. Guan, Catal. Sci. Technol., 2016, 6, 2930-2941.

[74] N. Feng, C. Chen, J. Meng, Y. Wu, G. Liu, L. Wang, H. Wan, G. Guan, Catal. Sci. Technol., 2016, 6, 7718-7728.

[75] N. Feng, C. Chen, J. Meng, G. Liu, F. Fang, L. Wang, H. Wan, G. Guan, Appl. Surf. Sci., 2017, 399, 114-122.

[76] N. Feng, C. Chen, J. Meng, G. Liu, F. Fang, J. Ding, L. Wang, H. Wan, G. Guan, Catal. Sci. Technol., 2017, 7, 2204-2212.

[77] P. Zhao, N. Feng, F. Fang, G. Liu, L. Chen, J. Meng, C. Chen, L. Wang, H. Wan, G. Guan, Catal. Sci. Technol., 2018, 8, 5462-5472.

[78] H. An, C. Kilroy, P. J. McGinn, Catal. Today, 2004, 98, 423-429.

[79] B. Białobok, J. Trawczyński, T. Rzadki, W. Miśta, M. Zawadzki, Catal. Today, 2007, 119, 278-285.

[80] B. Bai, J. Li, ACS Catal., 2014, 4, 2753-2762.

[81] A. Carrascull, I. D. Lick, E. N. Ponzi, M. I. Ponzi, Catal. Commun., 2003, 4, 124-128.

[82] C. F. Huo, B. S. Wu, P. Gao, Y. Yang, Y. W. Li, H. Jiao, Angew. Chem. Int. Ed., 2011, 50, 7403-7406.

[83] Y. Wei, L. Dang, X. Zhang, W. Cui, H. Wei, Fluid Phase Equilib., 2012, 318, 13-18.

[84] J. H. Park, A. H. Goldstein, J. Timkovsky, S. Fares, R. Weber, J. Karlik, R. Holzinger, Science, 2013, 341, 643-647.

[85] A. C. Lewis, Science, 2018, 359, 744-745.

[86] S. I. Suárez-Vázquez, S. Gil, J. M. García-Vargas, A. Cruz-López, A. Giroir-Fendler, Appl. Catal. B, 2018, 223, 201-208.

[87] L. Liu, J. Li, H. Zhang, L. Li, P. Zhou, X. Meng, M. Guo, J. Jia, T. Sun, J. Hazard. Mater., 2019, 362, 178-186.

[88] B. A. Tichenor, M. A. Palazzolo, Environ. Prog., 1987, 6, 172-176.

[89] J. Hermia, S. Vigneron, Catal. Today, 1993, 17, 349-358.

[90] H. Huang, Y. Liu, W. Tang, Y. Chen, Catal. Commun., 2008, 9, 55-59.

[91] S. Xie, H. Dai, J. Deng, Y. Liu, H. Yang, Y. Jiang, W. Tan, A. Ao, G. Guo, Nanoscale, 2013, 5, 11207-11219.

[92] H. Yang, J. Deng, Y. Liu, S. Xie, P. Xu, H. Dai, Chin. J. Catal., 2016, 37, 934-946.

[93] H. Yang, J. Deng, Y. Liu, S. Xie, Z. Wu, H. Dai, J. Mol. Catal. A, 2016, 414, 9-18.

[94] Y. Liu, H. Dai, Y. Du, J. Deng, L. Zhang, Z. Zhao, Appl. Catal. B, 2012, 119-120, 20-31.

[95] K. Ji, H. Dai, J. Deng, L. Zhang, F. Wang, H. Jiang, C.T. Au, Appl. Catal. A, 2012, 425-426, 153-160.

[96] K. Ji, H. Dai, J. Dai, J. Deng, F. Wang, H. Zhang, L. Zhang, Catal. Today, 2013, 201, 40-48.

[97] Z. Zhao, H. Dai, J. Deng, Y. Du, Y. Liu, L. Zhang, Microporous Mesoporous Mater., 2012, 163, 131-139.

[98] K. Ji, H. Dai, J. Deng, X. Li, Y. Wang, B. Gao, G. Bai, C.T. Au, Appl. Catal. A, 2012, 447, 41-48.

[99] Z. Zhao, H. Dai, J. Deng, Y. Du, Y. Liu, L. Zhang, J. Mol. Catal. A, 2013, 366, 116-125.

[100] K. Ji, H. Dai, J. Deng, H. Jiang, L. Zhang, H. Zhang, Y. Cao, Chem. Eng. J., 2013, 214, 262-271.

[101] K. Ji, H. Dai, J. Deng, L. Song, B. Gao, Y. Wang, X. Li, Appl. Catal. B, 2013, 129, 539-548.

[102] X. Li, H. Dai, J. Deng, Y. Liu, Z. Zhao, Y. Wang, H. Yang, C. T. Au,
Appl. Catal. A, 2013, 458, 11-20.

[103] Y. Liu, H. Dai, J. Deng, L. Zhang, B. Gao, Y. Wang, X. Li, S. Xie, G. Guo, Appl. Catal. B, 2013, 140-141, 317-326.

[104] X. Li, H. Dai, J. Deng, Y. Liu, S. Xie, Z. Zhao, Y. Wang, G. Guo, H. Arandiyan, Chem. Eng. J., 2013, 228, 965-975.

[105] K. Ji, H. Dai, J. Deng, H. Zhang, L. Zhang, H. Jiang, Solid State Sci., 2014, 27, 36-42.

[106] Y. Jiang, J. Deng, S. Xie, H. Yang, H. Dai, Ind. Eng. Chem. Res., 2015, 54, 900-910.

[107] Y. Jiang, S. Xie, H. Yang, J. Deng, Y. Liu, H. Dai, Catal. Today, 2017, 281, 437-446.

[108] W. Si, Y. Wang, S. Zhao, F. Hu, J. Li, Environ. Sci. Technol., 2016, 50, 4572-4578.

[109] S. S. Hong, G. D. Lee, Catal. Today, 2000, 63, 397-404.

[110] H. Wang, Z. Zhao, C. Xu, A. Duan, J. Liu, Y. Chi, Chin. J. Catal., 2008, 29, 649-654.

[111] N. Yamazoe, Y. Teraoka, Catal. Today, 1990, 8, 175-199.

[112] T. Nakamura, G. Petzow, L.J. Gauckler, Mater. Res. Bull., 1979, 14, 649-659.

[113] Y. Liu, H. Dai, J. Deng, L. Zhang, Z. Zhao, X. Li, Y. Wang, S. Xie, H. Yang, G. Guo, Inorg. Chem., 2013, 52, 8665-8676.

[114] J. M. Giraudon, A. Elhachimi, F. Wyrwalski, S. Siffert, A. Aboukaïs, J. F. Lamonier, G. Leclercq, Appl. Catal. B, 2007, 75, 157-166.

[115] M. Tian, C. He, Y. Yu, H. Pan, L. Smith, Z. Jiang, N. Gao, Y. Jian, Z. Hao, Q. Zhu, Appl. Catal. A, 2018, 553, 1-14.

[116] S. A. Montzka, E. J. Dlugokencky, J. H. Butler, Nature, 2011, 476, 43-50.

[117] X. Jiang, D. Mira, D. L. Cluff, Prog. Energy Combust. Sci., 2018, 66, 176-199.

[118] Q. Schiermeier, Nature, 2006, 439, 374-375.

[119] M. Cargnello, J. J. D. Jaén, J. C. H. Garrido, K. Bakhmutsky, T. Montini, J. J. C. Gámez, R. J. Gorte, P. Fornasiero, Science, 2012, 337, 713-717.

[120] P. Mars, D. W. van Krevelen, Chem. Eng. Sci., 1954, 3, 41-59.

[121] F. Zasada, J. Janas, W. Piskorz, M. Gorczyńska, Z. Sojka, ACS Catal., 2017, 7, 2853-2867.

[122] R. Burch, M. J. Hayes, J. Mol. Catal. A, 1995, 100, 13-33.

[123] X. Yang, Q. Gao, Z. Zhao, Y. Guo, Y. Guo, L. Wang, Y. Wang, W. Zhan, Appl. Catal. B, 2018, 239, 373-382.

[124] J. Yang, Y. Guo, Chin. Chem. Lett., 2018, 29, 252-260.

[125] M. Monai, T. Montini, M. Melchionna, T. Duchoň, P. Kúš, C. Chen, N. Tsud, L. Nasi, K. C. Prince, K. Veltruská, V. Matolín, M. M. Khader, R. J. Gorte, P. Fornasiero, Appl. Catal. B, 2017, 202, 72-83.

[126] Q. Huang, W. Li, Y. Lei, S. Guan, X. Zheng, Y. Pan, W. Wen, J. Zhu, H. Zhang, Q. Lin, Catal. Lett., 2018, 148, 2799-2811.

[127] P. Xu, X. Zhao, X. Zhang, L. Bai, H. Chang, Y. Liu, J. Deng, G. Guo, H. Dai, Mol. Catal., 2017, 439, 200-210.

[128] X. Li, Y. Liu, J. Deng, S. Xie, X. Zhao, Y. Zhang, K. Zhang, H. Arandiyan, G. Guo, H. Dai, Appl. Surf. Sci., 2017, 403, 590-600.

[129] J. Yuan, H. Dai, L. Zhang, J. Deng, Y. Liu, H. Zhang, H. Jiang, H. He, Catal. Today, 2011, 175, 209-215.

[130] V. Blasin-Aubé, J. Belkouch, L. Monceaux, Appl. Catal. B, 2003, 43, 175-186.

[131] M. Alifanti, M. Florea, V.I. Pârvulescu, Appl. Catal. B, 2007, 70, 400-405.

[132] H. Arandiyan, H. Dai, J. Deng, Y. Liu, B. Bai, Y. Wang, X. Li, S. Xie, J. Li, J. Catal., 2013, 307, 327-339.

[133] H. Arandiyan, J. Scott, Y. Wang, H. Dai, H. Sun, R. Amal, ACS Appl. Mater. Interfaces, 2016, 8, 2457-2463.

[134] X. Zhao, R. Zhang, Y. Liu, J. Deng, P. Xu, J. Yang, Z. Han, Z. Hou, H. Dai, C. T. Au, Appl. Catal. A, 2018, 568, 202-212. 
[135] H. Arandiyan, H. Dai, J. Deng, Y. Wang, S. Xie, J. Li, Chem. Commun., 2013, 49, 10748-10750.

[136] H. Arandiyan, H. Dai, J. Deng, Y. Wang, H. Sun, S. Xie, B. Bai, Y. Liu, K. Ji, J. Li, J. Phys. Chem. C, 2014, 118, 14913-14928.

[137] G. Guo, K. Lian, F. Gu, D. Han, Z. Wang, Chem. Commun., 2014, 50, 13575-13577.

[138] Y. Wang, H. Arandiyan, H. A. Tahini, J. Scott, X. Tan, H. Dai, J. D. Gale, A. L. Rohl, S. C. Smith, R. Amal, Nat. Commun., 2017, 8, 15553.

[139] K. Yu, D. Lei, Y. Feng, H. Yu, Y. Chang, Y. Wang, Y. Liu, G. C. Wang, L. L. Lou, S. Liu, W. Zhou, J. Catal., 2018, 365, 292-302.

[140] Y. Guo, S. Mei, K. Yuan, D. J. Wang, H. C. Liu, C. H. Yan, Y. W. Zhang, ACS Catal., 2018, 8, 6203-6215.

[141] H. Arandiyan, Y. Wang, J. Scott, S. Mesgari, H. Dai, R. Amal, ACS Appl. Mater. Interfaces, 2018, 10, 16352-16357.

[142] M. Tiemann, Chem. Eur. J., 2007, 13, 8376-8388.
[143] J. Xuan, L. P. Jiang, J. J. Zhu, Chin. J. Anal. Chem., 2010, 38, 513-516.

[144] Z. Wang, G. Men, R. Zhang, F. Gu, D. Han, Sensors Actuat. B, 2018, 263, 218-228.

[145] J. Qin, Z. Cui, X. Yang, S. Zhu, Z. Li, Y. Liang, Sensors Actuat. B, 2015, 209, 706-713.

[146] C. Balamurugan, S. J. Song, D. W. Lee, Sensors Actuat. B, 2018, $272,400-414$.

[147] T. Liu, Y. Zhang, X. Yang, X. Hao, X. Liang, F. Liu, F. Liu, X. Yan, J. Ouyang, G. Lu, Sensors Actuat. B, 2018, 276, 489-498.

[148] J. Qin, Z. Cui, X. Yang, S. Zhu, Z. Li, Y. Liang, J. Alloys Compd., 2015, 635, 194-202.

[149] N. Barsan, D. Koziej, U. Weimar, Sensors Actuat. B, 2007, 121, $18-35$.

[150] J. He, W. Zhou, J. Sunarso, X. Xu, Y. Zhong, Z. Shao, X. Chen, H. Zhu, Electrochim. Acta, 2018, 260, 372-383.

\title{
三维有序大孔钙钛矿材料在环境领域的应用
}

\author{
张晨曦, 赵培远 ${ }^{\mathrm{a}, \mathrm{c}}$, 刘双喜, ${ }^{\mathrm{a}, \mathrm{d}}$, 凯, ${ }^{\mathrm{b}, *}$ \\ a南开大学材料科学与工程学院新催化材料科学研究所, 国家新材料研究院, 天津 300350 , 中国

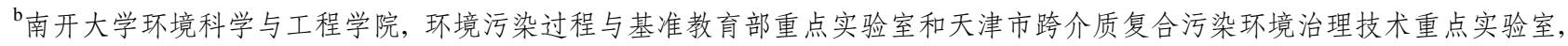 \\ 天津300350, 中国 \\ c新罕布什尔大学化学系, 达勒姆, 新罕布什尔州03824, 美国 \\ d 先进能源材料化学教育部重点实验室, 天津化学化工协同创新中心, 天津300072, 中国
}

摘要: 近年来, 三维有序大孔(3DOM)材料吸引了世界各国研究者的广泛关注. 除了表面积大、孔隙率高、孔体积大、传质 性能好等大孔材料的普遍特性, 3DOM材料的孔结构分布均匀, 且具有规律的周期性, 其大孔尺寸也可在制备过程中自由 调控. 在制备过程中, 通过加入适当的表面活性剂, 可以得到骨架上具有介孔的3DOM材料. 这使3DOM材料具有了多级孔 结构, 为其提供了更多的反应活性位点和对反应物的尺寸选择性. 此外, 作为一种三维光子晶体, 3DOM材料还具有光子禁 带、慢光效应等独特的光学性质.

钻钣矿是一类广泛分布于地球上且储量丰富的化合物, 具有成本低廉、氧化还原性能好、离子迁移率高、稳定性高、 毒性较低、生物相容性好等优点. 并且通过部分或完全取代钙钋矿材料中位于A位或B位的阳离子, 可以有效调控其物理化 学性质, 使其在环境领域中表现出巨大的应用潜力. 3DOM钻钛矿材料结合了 3DOM结构和钙钛矿材料各自的优点, 逐渐 成为了环境领域中的热门材料.已被广泛应用于光催化分解水产氢或降解污染物、碳烟催化燃烧、挥发性有机化合物 (VOCs)催化氧化、温室气体减排和利用、传感器等多种环境应用领域.

本文综述了近年来3DOM钻钣矿材料的一般合成方法, 并列举了3DOM钙针矿材料在环境领域的应用和研究进展, 详 细讨论了其在不同反应体系中的独特优势和反应机理. 除了 $3 \mathrm{DOM}$ 钻钛矿材料灵活的组成及可调变的物理化学性质对于 其催化性能的提升具有显著的作用. 此外, 在光催化中, 3DOM材料独特的慢光效应, 使半导体材料的光吸收范围与光子禁 带边重叠时, 可以显著提高半导体材料的光吸收效率, 进而有效提高催化剂的光催化活性. 因此, 3DOM材料的结构有序性 和光子禁带调控是3DOM钙铁矿材料在光催化领域应用中的关键因素. 对于碳烟催化燃烧, 由于碳烟颗粒尺寸较大, 碳烟 颗粒与催化活性位点的接触成为影响催化活性的关键因素. 因此, 3DOM钙钋矿材料的大孔孔径, 特别是其孔与孔之间的 窗口尺寸对于其催化性能起着重要的作用. 而对于VOCs催化氧化、 $\mathrm{CH}_{4}$ 催化燃烧、 $\mathrm{CO}_{2}$ 甲烷化、传感器等应用领域, 3DOM 钙铁矿材料比表面积的提升以及多级孔道结构的构建对催化活性的促进作用更为显著. 最后, 本文提出了该研究领域所 面临的挑战, 并对未来的发展进行了展望.

关键词: 三维有序大孔材料; 钻钛矿; 环境应用; 光催化; 催化氧化; $\mathrm{CO}_{2}$ 甲烷化; 传感器

收稿日期: 2019-01-02. 接受日期: 2019-03-03. 出版日期: 2019-09-05.

*通讯联系人. 电话: (022)85358635; 电子信箱: kaiyu@nankai.edu.cn

基金来源：天津市自然科学基金(17JCYBJC22600); 中央高校基本科研业务费专项资金.

本文的电子版全文由Elsevier出版社在ScienceDirect上出版(http://www.sciencedirect.com/science/journal/18722067). 